\title{
Comparison of the meteorology and surface energy fluxes of debris-free and debris-covered glaciers in the southeastern Tibetan Plateau
}

\author{
WEI YANG ${ }^{1,2}$ TANDONG YAO, $^{1,2}$ MEILIN ZHU, ${ }^{1}$ YONGJIE WANG ${ }^{1}$ \\ ${ }^{1}$ Key Laboratory of Tibetan Environment Changes and Land Surface Processes, Institute of Tibetan Plateau Research, \\ Chinese Academy of Sciences (CAS), Beijing, China \\ ${ }^{2}$ CAS Center for Excellence in Tibetan Plateau Earth Sciences, Beijing 100101, China \\ Correspondence: Wei Yang <yangww@itpcas.ac.cn>
}

\begin{abstract}
Knowledge of debris-free and debris-covered glaciers is important for understanding the varying response of glaciers to climate change. Measurements at the debris-free Parlung No. 4 Glacier and the debris-covered $24 \mathrm{~K}$ Glacier in the southeastern Tibetan Plateau were carried out to compare the meteorology and surface energy fluxes and to understand the factors controlling the melting process. The meteorological comparisons displayed temporally synchronous fluctuations in air temperature, relative humidity and incoming longwave radiation $\left(L_{\text {in }}\right)$, but notable differences in precipitation, incoming shortwave radiation $\left(S_{i n}\right)$ and wind speed. Under the prevailing regional precipitation and debris conditions, more $\boldsymbol{L}_{\text {in }}\left(42 \mathrm{~W} \mathrm{~m}^{-2}\right)$ was supplied from warmer and more humid air and more $S_{\text {in }}\left(58 \mathrm{~W} \mathrm{~m}^{-2}\right)$ was absorbed at the $24 \mathrm{~K}$ Glacier. The relatively high energy supply led mainly to an increased energy output via turbulent heat fluxes and outgoing longwave radiation, rather than glacier melting beneath the thick debris. The sensitivity experiment showed that melt rates were sensitive to energy supply at debris thicknesses $<\sim 10 \mathrm{~cm}$. In contrast, energy supply to the Parlung No. 4 Glacier mainly resulted in snow/ice melting, the magnitude of which was significantly influenced by energy supplied by $S_{\text {in }}$ and the sensible heat flux.
\end{abstract}

KEYWORDS: debris-covered glaciers, energy balance, glacier meteorology, glacier modeling, mountain glaciers

\section{INTRODUCTION}

The glaciers in the Himalaya and Tibetan Plateau are the sources of the major rivers of Asia (Immerzeel and others, 2010), and in addition, their status is a sensitive indicator of regional climate change at high altitudes where few meteorological data are available. Both debris-free (clean) glaciers and debris-covered glaciers are common in the Himalaya and Tibetan Plateau (Benn and others, 2012). Debris cover can either increase or decrease ablation rates depending on debris thickness (Østrem, 1959), thus influencing glacier mass balance and dynamic behavior (Anderson and Mackintosh, 2012; Nicholson and Benn, 2012). Debris cover is regarded as a potential contributor to the heterogeneous pattern of glacier changes in the Himalaya and Tibetan Plateau (Scherler and others, 2011). Understanding the different mechanisms controlling changes in both debris-free and debris-covered glaciers is therefore important for predicting glacial runoff and the future response of glaciers to climate change (Bolch and others, 2012).

A prerequisite for understanding glacier behavior is a comprehensive understanding of local meteorological conditions and the surface energy balance, which provide important insights into surface/atmosphere interactions at high elevations (Brock and others, 2010; Mölg and others, 2014). Meteorological measurements and energy-balance modeling has been carried out on mountain glaciers and ice sheets worldwide on debris-free (e.g. van den Broeke, 1997; Giesen and others, 2008; Nicholson and others, 2013) and debris-covered glaciers (e.g. Brock and others,
2010; Reid and Brock, 2010; Anderson and Mackintosh, 2012; Reid and others, 2012). However, obtaining in situ records of glacial meteorology and energy balance is often difficult because of the logistical problems involved in operating in the harsh high-altitude environment of the Himalaya and Tibetan Plateau. In addition, the complex orography results in major climatic variability over short horizontal/vertical distances (Maussion and others, 2013) and the representativeness of limited measurements needs to be addressed.

Previous detailed meteorological and energy-balance studies in the Himalaya and Tibetan Plateau have mainly focused on debris-free glaciers (e.g. Yang and others, 2011; Azam and others, 2014; Sun and others, 2014; Huintjes and others, 2015). Most of the studies of debris-covered glaciers have focused on the following issues: the effect of debris cover on glacier ablation and runoff using different models (e.g. Han and others, 2006; Fujita and Sakai, 2014; Collier and others, 2015; Rowan and others, 2015; Steiner and others, 2015; Zhang and others, 2016); debris thermal resistance and thickness estimation using remote-sensing data (e.g. Nakawo and Rana, 1999; Mihalcea and others, 2008; Zhang and others, 2011; Rounce and McKinney, 2014; Schauwecker and others, 2015); and debris properties and ablation (e.g. Mihalcea and others, 2006; Hagg and others, 2008; Rounce and others, 2015). Although there have been a few attempts to conduct detailed in situ meteorological and surface energy-balance measurements on debris-covered glaciers (e.g. Takeuchi and others, 2000; Sakai and others, 2002; Steiner and Pellicciotti, 2015; Shea and others, 2015; 
Shaw and others, 2016), there is a lack of synchronous comparative studies of debris-covered and debris-free glaciers on a seasonal scale. Consequently, it is difficult to conduct an in-depth quantitative assessment of regional glacier response to climate change (Scherler and others, 2011) and to evaluate statistically/dynamically downscaled climate fields in mountainous regions (Hofer and others, 2015).

Here we present the results of a synchronous study of the meteorology and surface energy balance in the ablation zones of the debris-free Parlung No. 4 Glacier and debriscovered $24 \mathrm{~K}$ Glacier, which are $120 \mathrm{~km}$ apart in the southeastern Tibetan Plateau. The study was conducted in the ablation season (June-September) of 2016 using the data from two automatic weather stations (AWSs) and ablation measurements. The aims were as follows: (1) to investigate the similarities and differences of micrometeorological variables between the two types of glacier under the same influence of the Indian summer monsoon; and (2) to shed light on the differences in the energy balance between debris-free and debris-covered glaciers and subsequently to quantify their controls. It was hoped that the results of the study would reduce the uncertainties involved in future glaciological and hydrological modeling, and improve our knowledge of glacier/climate interactions in this mountainous monsoon-influenced glacierized region.

\section{STUDY SITES AND MEASUREMENTS}

\subsection{Study sites}

The study region is located in the southeastern Tibetan Plateau at the junction between the eastern Himalaya, eastern Nyainqentanglha Mountain and the western Hengduan Mountains (Fig. 1). Rotational deformation resulting from the collision of the Indian and Eurasian plates has produced an undulating terrain with deep valleys and high mountains, ranging from $\sim 100 \mathrm{~m}$ a.s.l. to the highest peak in NamchaBarwa (7782 $\mathrm{m}$ a.s.I.). As a consequence of the tectonic activity, the Brahmaputra River turns from a west-east to a north-south direction and flows through a deep gorge, called the Grand Canyon. The Indian summer monsoon impinges on the Tibetan Plateau along this Grand Canyon (Ye and Gao, 1979). The combination of the complex local topography and the Indian summer monsoon system results in a glacierized region of $\sim 9470 \mathrm{~km}^{2}$ at high elevations (Shi and others, 2008). As a result of recent climatic warming and decrease in monsoonal precipitation, glaciers in this region are retreating and experiencing significant mass loss (Yao and others, 2012; Kääb and others, 2015; Yang and others, 2016; Brun and others, 2017).

Two glaciers (Parlung No. 4 Glacier and $24 \mathrm{~K}$ Glacier, $120 \mathrm{~km}$ apart) were selected as benchmark glaciers for meteorological and energy-balance comparisons in this region (Figs 1 and 2). The Parlung No. 4 Glacier $\left(29^{\circ} 14^{\prime} \mathrm{N}\right.$, $\left.96^{\circ} 56^{\prime} \mathrm{E}\right)$ is a debris-free valley glacier, which flows from $5964 \mathrm{~m}$ a.s.l. to $4650 \mathrm{~m}$ a.s.l., with an area of $\sim 11.7 \mathrm{~km}^{2}$ and a length of nearly $8 \mathrm{~km}$. It is located on the northern slope of eastern Mount Gangrigabu, the ridge altitude of which increases from west to east. The $24 \mathrm{~K}$ Glacier $\left(29^{\circ}\right.$ $\left.45^{\prime} \mathrm{N}, 95^{\circ} 43^{\prime} \mathrm{E}\right)$ was selected as a comparative glacier on the western slopes of Mount Gangrigabu, and is closer to the Brahmaputra River. It is an avalanche-fed debriscovered valley glacier with $\sim 47 \%$ of the total glacier area covered by debris. The $24 \mathrm{~K}$ Glacier has a lower average elevation range (from 3880 to $4800 \mathrm{~m}$ a.s.l.) and a smaller glacier area $\left(2.7 \mathrm{~km}^{2}\right)$ than the Parlung No. 4 Glacier. The debris thickness ranges from $\sim 0.7 \mathrm{~m}$ at the terminus to sparse thin layers in the upper region at $\sim 4200 \mathrm{~m}$ a.s.l. (Yang and others, 2010). Bomi city (2737 m a.s.l.), for which long-term meteorological records are available, is located in the lower part of the valley of the $24 \mathrm{~K}$ Glacier (Fig. 1).

\subsection{Surface meteorological and ablation measurements}

The AWSs were installed at $4800 \mathrm{~m}$ a.s.I. and $3900 \mathrm{~m}$ a.s.I. in the ablation zones of Parlung No. 4 Glacier and 24 K Glacier, respectively (Fig. 2). Both AWSs recorded meteorological variables (air temperature, relative humidity, wind speed/direction, incoming/outgoing shortwave and longwave radiation, and air pressure) at 30 min intervals using Campbell Scientific data loggers. The lithology of the debris surrounding the AWS at $24 \mathrm{~K}$ Glacier consists primarily of granites, schists and sandstones. The debris sizes are heterogeneous with boulders ranging up to $0.5 \mathrm{~m}$ overlying a surface with both fine-grained and gravel materials. Three debris temperature sensors were deployed at 5, 10 and $20 \mathrm{~cm}$ depth to measure the internal debris temperature of a $25 \mathrm{~cm}$ thick layer near the AWS at $24 \mathrm{~K}$ Glacier. All-phase precipitation at Parlung No. 4 Glacier was measured using a Geonor T-200B weighing bucket gauge, which was installed $\sim 5.6 \mathrm{~km}$ north of the glacier terminus. Rainfall at $24 \mathrm{~K}$ Glacier was recorded using a tipping bucket $\mathrm{HOBO}$ RG3 rain gauge near the AWS. The records of surface albedo at both AWSs evidenced that most precipitation fell as rain on both glaciers during the observational periods. Wind direction data for Parlung No. 4 Glacier are not available due to an instrumental problem in 2016. The relevant surface meteorology and energy budget during the 2009 ablation season at Parlung No. 4 Glacier has been analyzed previously and detailed instrumental information was given in Yang and others (2011). Table 1 only lists the specifications of the AWS on the debris-covered $24 \mathrm{~K}$ Glacier. The AWSs were maintained for sensor leveling at monthly intervals from June to September, 2016.

One PVC ablation stake was inserted into the ice using a Heucke ice drill to measure ablation near each AWS on the two glaciers. The debris thickness at the ablation stake near the AWS on $24 \mathrm{~K}$ Glacier is $\sim 20 \mathrm{~cm}$. In order to assess the relationship between glacier melting and debris thickness, a total of 11 ablation stakes under debris thicknesses ranging from 36 to $1 \mathrm{~cm}$ were also deployed along the central axis of $24 \mathrm{~K}$ Glacier (Fig. 2). The ablation at each stake was measured during the maintenance of the AWSs. The stake data were converted to w.e. using an ice density of $900 \mathrm{~kg} \mathrm{~m}^{-3}$.

\section{METHODS}

\subsection{Debris-free glacier energy-balance model}

The surface energy-balance model on the debris-free Parlung No. 4 Glacier is described in detail by Yang and others (2011). The primary components can be specified as:

$$
S_{\text {in }}+S_{\text {out }}+L_{\text {in }}+L_{\text {out }}+H_{\text {sen }}+H_{\text {lat }}+G_{\mathrm{p}}+G_{\mathrm{i}}+Q_{\text {melting }}=0
$$

where $S_{\text {in }} / S_{\text {out }}$ are the incoming/reflected shortwave radiation; $L_{\text {in }} / L_{\text {out }}$ are incoming/outgoing longwave radiation; 


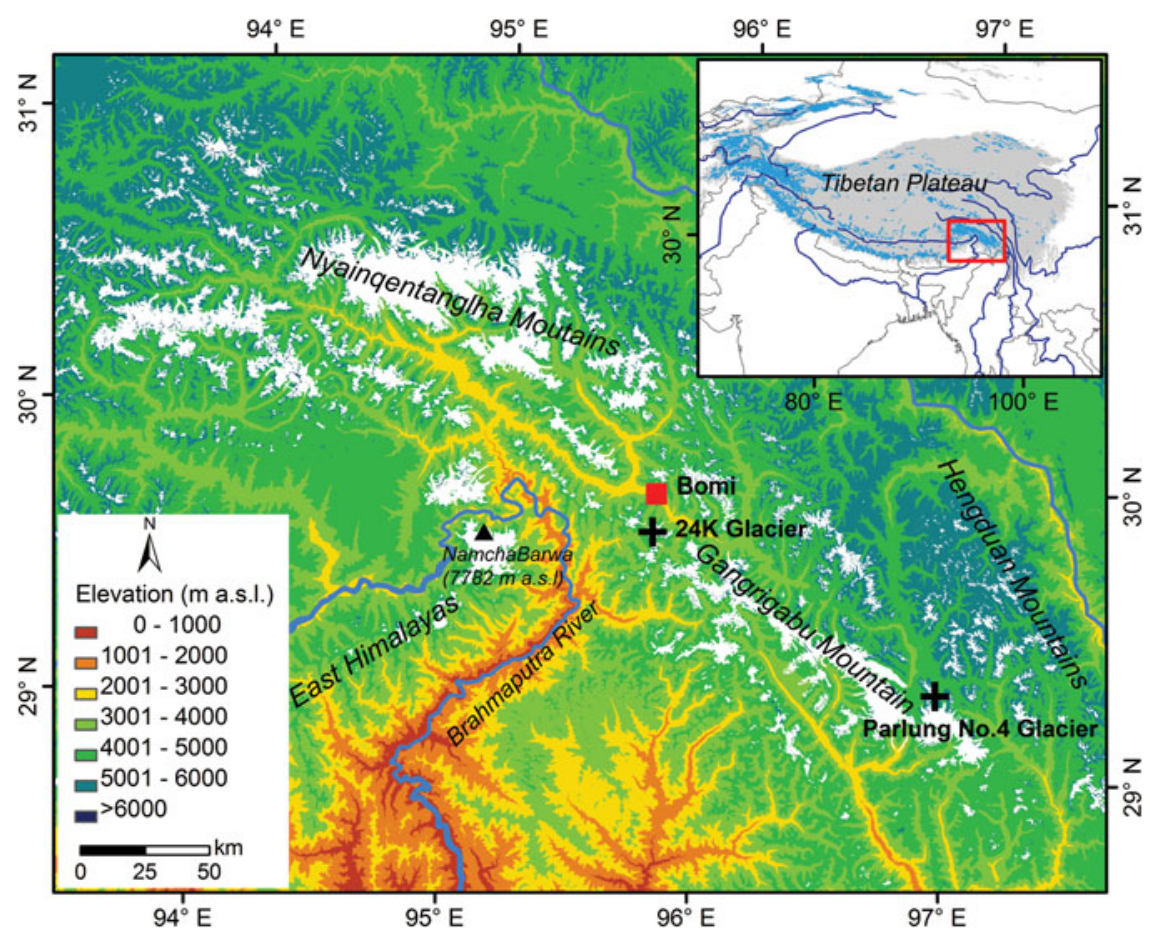

Fig. 1. The study region of the southeastern Tibetan Plateau: topography, glacier distribution (white shading) and locations of the debriscovered $24 \mathrm{~K}$ Glacier and debris-free Parlung No. 4 Glacier (black crosses) and the Bomi meteorological station (red square). Inset map shows the location of the study region in Asia.
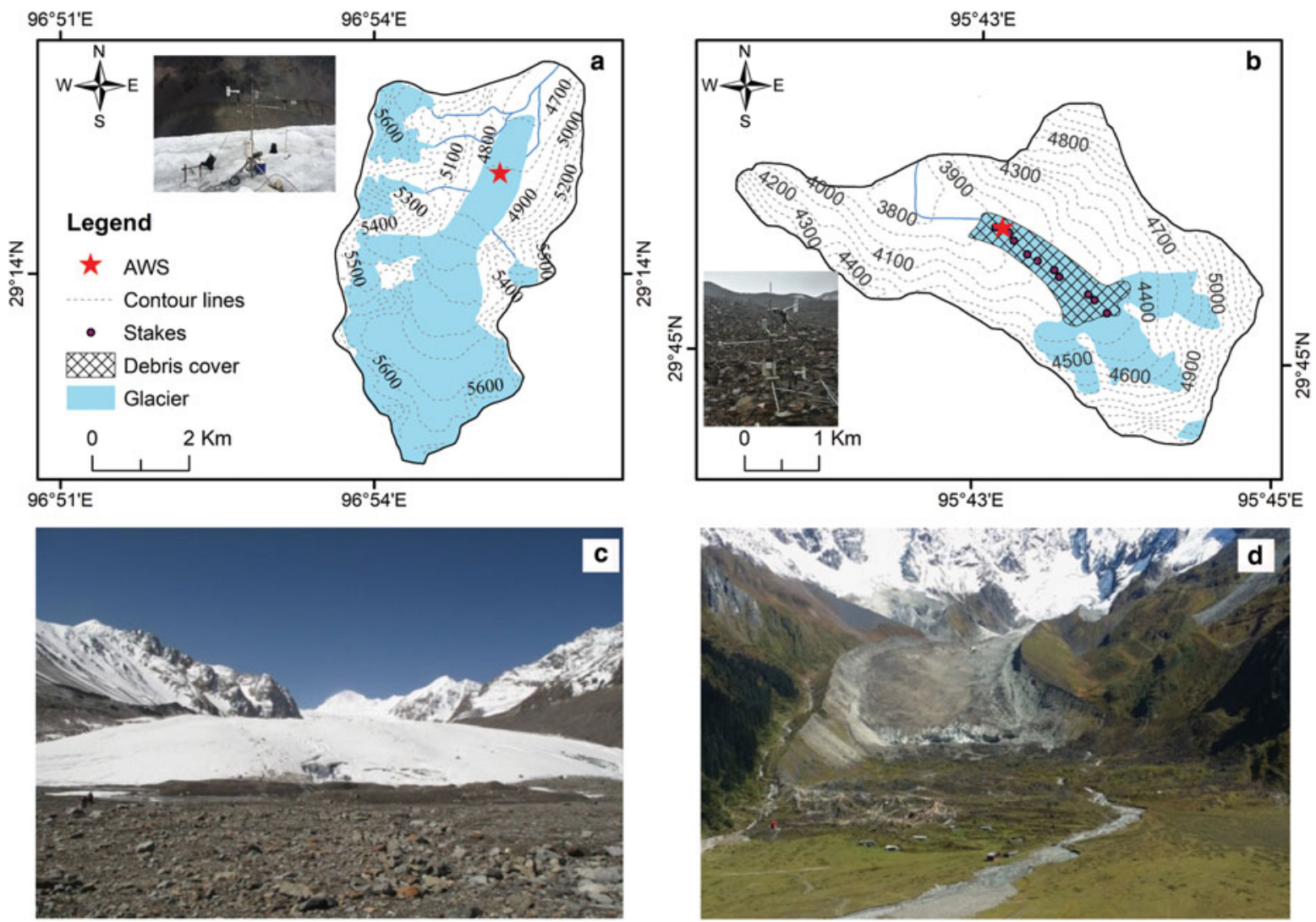

Fig. 2. Topography and meteorological and glaciological monitoring at the Parlung No. 4 Glacier (a, c) and 24 K Glacier (b, d), together with the distribution of ablation stakes in the debris-covered zone. Note the different scales. The photographs shows the AWSs $(a, b)$ and the surface types (c, d) on the respective glaciers.

$H_{\text {sen }}$ and $H_{\text {lat }}$ are the sensible and latent turbulent fluxes, respectively; $G_{p}$ is sensible heat energy supplied or consumed by precipitation falling on the surface; $G_{\mathrm{i}}$ is the subsurface heat flux in snow/ice; and $Q_{\text {melting }}$ is the melting energy. Fluxes are positive when directed towards the surface and units are $\mathrm{W} \mathrm{m}^{-2}$. The turbulent fluxes were calculated using the bulk aerodynamic method and the subsurface heat flux was estimated using a simple two-layer 
Table 1. Specifications of the automatic weather station instrumentation on the debris-covered $24 \mathrm{~K}$ Glacier

\begin{tabular}{|c|c|c|c|}
\hline Quantity & Sensor & Height & Accuracy \\
\hline Air temperature $\left(T_{\text {air }}\right),{ }^{\circ} \mathrm{C}$ & Vaisala HMP155 & $2 \mathrm{~m}$ & $\pm 0.17^{\circ} \mathrm{C}$ \\
\hline Relative humidity $(R H), \%$ & Vaisala HMP155 & $2 \mathrm{~m}$ & $\pm 1 \%$ in $0-90 \%, \pm 1.7 \%$ in $90-100 \%$ \\
\hline Wind speed $(u), \mathrm{m} \mathrm{s}^{-1}$ & Young 05103-L & $1,2 \mathrm{~m}$ & $\pm 0.3 \mathrm{~m} \mathrm{~s}^{-1}$ \\
\hline Wind direction, $^{\circ}$ & Young 05103-L & $1,2 \mathrm{~m}$ & $\pm 3^{\circ}$ \\
\hline Incident shortwave radiation $\left(S_{\text {in }}\right), \mathrm{W} \mathrm{m}^{-2}$ & Hukseflux NR01 & $2 \mathrm{~m}$ & $1.9-4.5 \%$ \\
\hline Reflected shortwave radiation $\left(S_{\text {out }}\right), \mathrm{W} \mathrm{m}^{-2}$ & Hukseflux NR01 & $2 \mathrm{~m}$ & $1.9-4.5 \%$ \\
\hline Incoming longwave radiation $\left(L_{\mathrm{in}}\right), \mathrm{W} \mathrm{m}^{-2}$ & Hukseflux NR01 & $2 \mathrm{~m}$ & $1.9-4.5 \%$ \\
\hline Outgoing longwave radiation $\left(L_{\text {out }}\right), \mathrm{W} \mathrm{m}^{-2}$ & Hukseflux NR01 & $2 \mathrm{~m}$ & $1.9-4.5 \%$ \\
\hline Debris temperature $\left(T_{\mathrm{d}}\right),{ }^{\circ} \mathrm{C}$ & Campbell Scientific CS655-L & $-5,-10,-20 \mathrm{~cm}$ & $\pm 0.5^{\circ} \mathrm{C}$ \\
\hline Precipitation (Prec), mm & Onset HOBO RG3-M & $1.5 \mathrm{~m}$ & $0.2 \mathrm{~mm}$ \\
\hline
\end{tabular}

subsurface model:

$$
\begin{gathered}
H_{\text {sen }}=\rho_{\text {air }} C_{\mathrm{p}} u_{*} T_{*} \\
H_{\text {lat }}=\rho_{\text {air }} \lambda_{\mathrm{s}} u_{*} q_{*} \\
G_{\mathrm{p}}=\rho_{\mathrm{w}} C_{\mathrm{w}} w\left(T_{\text {air }}-T_{\mathrm{s})}\right. \\
G_{\mathrm{i}}=\rho_{\text {ice }} C_{\mathrm{s}} K_{\mathrm{s}} \frac{\partial T_{\text {ice }}}{\partial z}
\end{gathered}
$$

where $\rho_{\text {air }} \rho_{\text {ice }}$ and $\rho_{\mathrm{w}}$ are the density of air, ice and water $\left(\mathrm{kg} \mathrm{m}^{-3}\right) ; c_{\mathrm{p}}, C_{\mathrm{s}}$ and $C_{\mathrm{w}}$ are the specific heat capacity of air, ice and water, respectively $\left(1005 \mathrm{~J} \mathrm{~kg}^{-1} \mathrm{~K}^{-1}, 2090 \mathrm{~J} \mathrm{~kg}^{-1} \mathrm{~K}^{-1}\right.$, $\left.4181 \mathrm{~J} \mathrm{~kg}^{-1} \mathrm{~K}^{-1}\right) ; \lambda_{\mathrm{s}}$ is the latent heat for sublimation $\left(2.834 \times 10^{6} \mathrm{~J} \mathrm{~kg}^{-1}\right)$ or evaporation $\left(2.514 \times 10^{6} \mathrm{~J} \mathrm{~kg}^{-1}\right) ; u_{*}$, $T_{*}$ and $q_{*}$ are defined in Yang and others (2011) with $u_{*}$ the friction velocity, and $T_{*}$ and $q_{*}$ the scaling parameters for air temperature $\left(T_{\text {air }}\right)$ and specific humidity $\left(q_{\text {air }}\right)$, respectively; $w$ is the rainfall rate $\left(\mathrm{m} \mathrm{s}^{-1}\right) ; K_{\mathrm{s}}$ is the thermal diffusivity of ice $\left(1.15 \times 10^{-6} \mathrm{~m}^{2} \mathrm{~s}^{-1}\right) ; T_{\mathrm{s}}$ is surface temperature $(\mathrm{K}) ; T_{\text {ice }}$ is the ice temperature at different depths $(z)$. The parameters and model performance for turbulent heat fluxes and melting were validated using eddy-covariance measurements and ablation stakes during the 2009 ablation season. For detailed model information and relevant parameters see Yang and others (2011), Guo and others (2011) and Reid and Brock (2010).

The eddy-covariance system has been moved from the AWS on Parlung No. 4 Glacier and thus the ablation recorded by the stake at different time intervals was used to corroborate the modeling accuracy during the 2016 ablation season. Figure 3a shows the modeled and measured cumulative ablation during the period from 1 June to 30 September
2016, and it is clear that modeled ablation closely matches the ablation measured by stakes. The total ablation calculated using the ablation stake and surface energy-balance model was -4.3 and $-4.4 \mathrm{~m}$ w.e., respectively. Derived from the measurements and modeled outputs at five observational intervals, the mean absolute error was $0.12 \mathrm{~m}$ w.e., with RMSE of $0.15 \mathrm{~m}$ w.e. This result increases our confidence in the accuracy of radiation measurements and in the model's ability to capture the surface turbulent heat fluxes.

\subsection{Debris-covered glacier energy balance}

Compared with debris-free glaciers, estimating the energy balance of a debris-covered surface is complicated by the highly variable surface debris temperature, surface humidity and thermal properties of the debris. The debris energybalance model (DEB model) proposed by Reid and Brock (2010) was adopted in this study. The surface temperature was iteratively calculated in the model and detailed information about the parameters and detailed model description are given in Reid and Brock (2010). Its primary components are:

$$
\begin{gathered}
S_{\text {in }}+S_{\text {out }}+L_{\text {in }}+L_{\text {out }}+H_{\text {sen }}+H_{\text {lat }}+G_{\mathrm{p}}+G_{\mathrm{d}}=0 \\
H_{\text {sen }}=\rho_{\text {air }} \frac{c_{\mathrm{p}} k^{2} u\left(T_{\text {air }}-T_{\mathrm{s}}\right)}{\left(\ln \left(z_{\mathrm{a}} / z_{0 m}\right)\right)\left(\ln \left(z_{\mathrm{a}} / z_{0 t}\right)\right)}\left(\Phi_{\mathrm{m}} \Phi_{\mathrm{h}}\right)^{-1} \\
H_{\text {lat }}=\rho_{\text {air }} \frac{\lambda_{\mathrm{s}} k^{2} u\left(q_{\text {air }}-q_{\mathrm{s}}\right)}{\left(\ln \left(z_{\mathrm{a}} / z_{0 m}\right)\right)\left(\ln \left(z_{\mathrm{a}} / z_{0 q}\right)\right)}\left(\Phi_{\mathrm{m}} \Phi_{\mathrm{v}}\right)^{-1} \\
G_{\mathrm{d}}=k_{\mathrm{d}} \frac{T_{\mathrm{d}}(1)-T_{\mathrm{s}}}{h}
\end{gathered}
$$
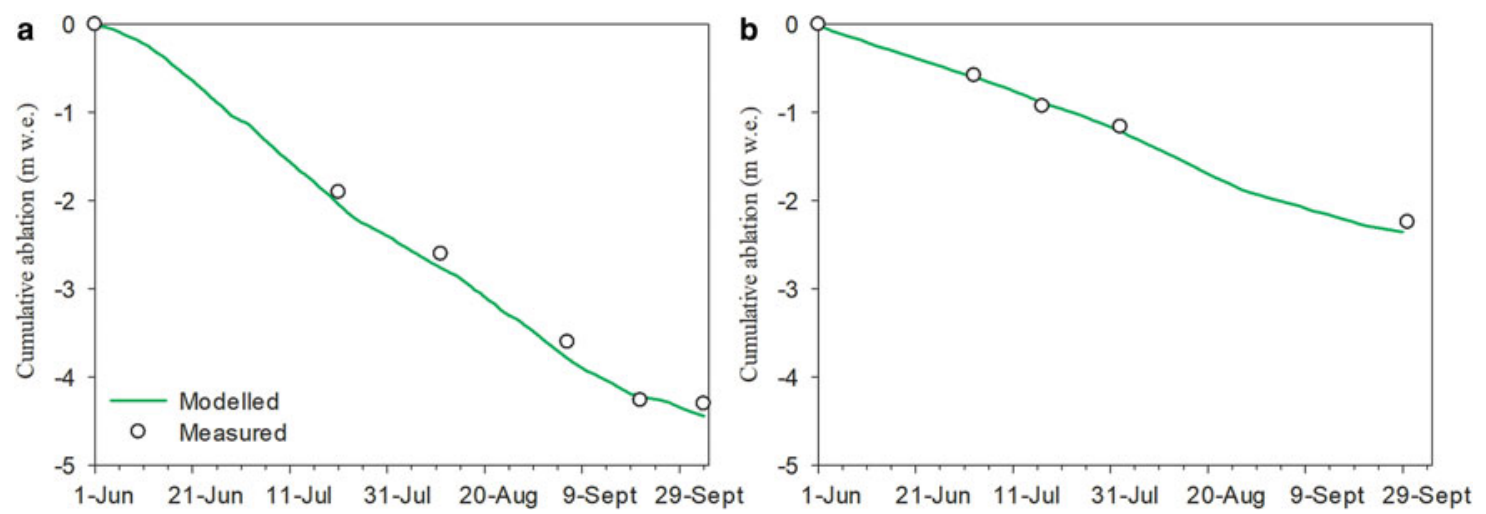

Fig. 3. Modeled and measured cumulative ablation near the AWS of Parlung No. 4 Glacier (a) and of 24 K Glacier (b). Circles represent measurements by ablation stakes. 
where $G_{d}$ is the conductive heat flux $\left(\mathrm{W} \mathrm{m}^{-2}\right) ; k$ is von the Karman's constant $(0.41) ; u$ is the wind speed $\left(\mathrm{m} \mathrm{s}^{-1}\right) ; z_{0 m}$ $z_{0 t}, z_{0 q}$ are surface roughness lengths $(m)$ for momentum, heat and humidity, respectively (assuming $z_{0 m}=z_{0 t}=z_{0 q}$ ); $q_{\text {air }}$ and $q_{\mathrm{s}}$ are the specific humidity at the measurement height $\left(z_{a}=2 \mathrm{~m}\right)$ and at the surface, respectively; $\Phi_{\mathrm{m}}, \Phi_{\mathrm{v}}$, $\Phi_{\mathrm{h}}$ are nondimensional stability functions for momentum, moisture and heat, respectively; $k_{\mathrm{d}}$ is thermal conductivity of debris $\left(\mathrm{W} \mathrm{m}{ }^{-1} \mathrm{~K}^{-1}\right) ; T_{\mathrm{d}}$ is the debris temperature for different depths $(K)$; and $h$ is the thickness of each layer $(0.01 \mathrm{~m})$. Fluxes are also positive when directed towards the surface. The debris temperature in contact with the ice surface was assumed to be continuously at melting point throughout the observational period.

It is difficult to determine the latent heat flux without detailed knowledge of the relative humidity at the surface. Precipitation was abundant at $24 \mathrm{~K}$ Glacier, and following, more or less, the method similar to that of Rounce and others (2015), the surface relative humidity of the debris was assumed to be $100 \%$ when it was raining (hourly total precipitation above $0.2 \mathrm{~mm}$ ) and $0 \%$ when the debris was dry $\left(H_{\text {lat }}=0\right)$.

Based on the linear function of the debris mean temperature recorded by three debris thermal sensors, the mean debris thermal conductivity $\left(K_{\mathrm{d}}=1.33 \mathrm{~W} \mathrm{~m}^{-1} \mathrm{~K}^{-1}\right)$ was determined using the average thermal gradients and the in situ ablation measurements near the AWS (Drewry, 1972) and was subsequently assumed to be constant in the model. The $K_{\mathrm{d}}$ at $24 \mathrm{~K}$ Glacier was within the ranges reported by previous studies in the Himalaya (e.g. Nakawo and Young, 1982; Rounce and others, 2015). With regard to the visibly greater roughness near the AWS (see the photograph in Fig. 2b) and the possible roughness boundaries (Rounce and others, 2015), the $z_{0 m}(0.028 \mathrm{~m})$ was optimized to guarantee the minimum RMSE between the modeled and measured ablation during the observational period (Fig. 3b). The model was run using hourly-averaged values of meteorological variables and the debris temperature.

The modeling performance was validated using in situ measurements, including surface temperature $\left(T_{\mathrm{s}}\right)$ derived from measured $L_{\text {out }}$ assuming that the debris acts as a black body, the debris temperature data at $5 \mathrm{~cm}, 10 \mathrm{~cm}$ and $20 \mathrm{~cm}$ depth near the AWS during the observational period. Figure 4 compares the simulated and measured surface temperature and internal debris temperature at different depths. The Nash-Sutcliffe model efficiency coefficient $\left(E_{N S}\right)$ between modeled and measured $T_{\mathrm{s}}$ and within-debris temperature at $5 \mathrm{~cm}, 10 \mathrm{~cm}$ and $20 \mathrm{~cm}$ depth demonstrated that the DEB model can reproduce the hourly variations with a good degree of fit (Fig. 4). The RMSE values between modeled and measured hourly $T_{\mathrm{s}}$ and debris temperature at the three depths were $2.0,2.0,0.9$ and $0.8^{\circ} \mathrm{C}$, respectively. These multi-method comparisons indicated that the DEB model captures the primary processes, as well as demonstrating the appropriateness of the relevant parameters.

\subsection{Data processing under varying weather conditions}

To compare the variation of atmospheric variables and energy fluxes in different weather conditions, we categorized subsets of the data for clear-sky and overcast conditions. Cloudiness index was firstly estimated from the measured incoming longwave radiation and air temperature, following the method suggested by van den Broeke and others (2006) and Giesen and others (2008). Polynomial fits through the 5th and 95th percentile levels of the incoming longwave radiation, binned into air temperature intervals of $0.5 \mathrm{~K}$, are assumed to represent the minimum and maximum possible incoming longwave radiation at a given air temperature, corresponding to a cloudiness of 0 and 1 , respectively. Assuming cloudiness increases linearly between these two limits, linear interpolation was used to calculate the cloud index for each hourly interval from corresponding measurements of the air temperature and incoming longwave radiation. We defined clear-sky conditions to occur when cloudiness values were $<0.4$ and overcast conditions when cloudiness values exceeded 0.9. Using this definition, atmospheric variables and energy fluxes for these contrasting weather conditions were compared in the following sections.

\section{RESULTS}

\subsection{Surface meteorological comparison of debris-free and debris-covered glaciers}

\subsubsection{Air temperature and relative humidity}

Mean air temperature at $24 \mathrm{~K}$ Glacier was $5.4^{\circ} \mathrm{C}$ higher than at Parlung No.4 Glacier, reflecting differences in elevation and surface type (Table 2). Because excess energy is used for melting the snow/ice surface at Parlung No. 4 Glacier, the overlying air is cooled (e.g. van den Broeke, 1997; Greuell and Böhm, 1998) and the daily mean temperature on Parlung No. 4 Glacier rarely exceeded $6^{\circ} \mathrm{C}$. In contrast, the air is warmed by radiative and convective heating from the underlying debris during daytime (Brock and others, 2010). These cooling/warming effects contribute to the observed differences in daily and diurnal temperature variations between the debris-free Parlung No. 4 Glacier and the debris-covered $24 \mathrm{~K}$ Glacier (Figs 5a and 6a). The Std dev.s/ diurnal amplitudes were $1.0 / 3.5^{\circ} \mathrm{C}$ and $1.5 / 4.7^{\circ} \mathrm{C}$ for Parlung No. 4 Glacier and $24 \mathrm{~K}$ Glacier, respectively. The warming effect at the debris-covered surface was particularly significant in clear-sky weather conditions (Fig. 7a and Table 3). The averaged air temperature in clear-sky conditions was $\sim 1.1^{\circ} \mathrm{C}$ higher than that in the overcast conditions at $24 \mathrm{~K}$ Glacier, in comparison with the value of $0.5^{\circ} \mathrm{C}$ at Parlung No. 4 Glacier. The difference in diurnal amplitude between clear-sky conditions and overcast conditions was $5.5^{\circ} \mathrm{C}$ at $24 \mathrm{~K}$ Glacier, but only $2.0^{\circ} \mathrm{C}$ at Parlung No. 4 Glacier (Fig. 7a). This indicates that under clear-sky conditions, the presence of a thick debris layer greatly influences the air temperature, which was mainly driven by convective and radiative heating during daytime and cooling by sensible heat transfer at nighttime. Overall, the daily air temperatures at both glaciers were significantly correlated with a correlation coefficient of $0.6(p<0.01)$.

The air was very humid at both glaciers with an average relative humidity of $\sim 81 \%$ (Fig. $5 \mathrm{~b}$ and Table 2 ). In addition, the fluctuations in daily relative humidity at both glaciers were similar, with a correlation coefficient of $0.71(p<$ 0.01). Dramatic shifts from low to high humidity occurred in mid-June at both glaciers. In terms of diurnal fluctuations, both glaciers exhibited higher relative humidity during nighttime but drier air conditions during the afternoon (Fig. 6b). In contrast with the uniformity of the values on the debris surface during nighttime, the relative humidity at the snow/ 

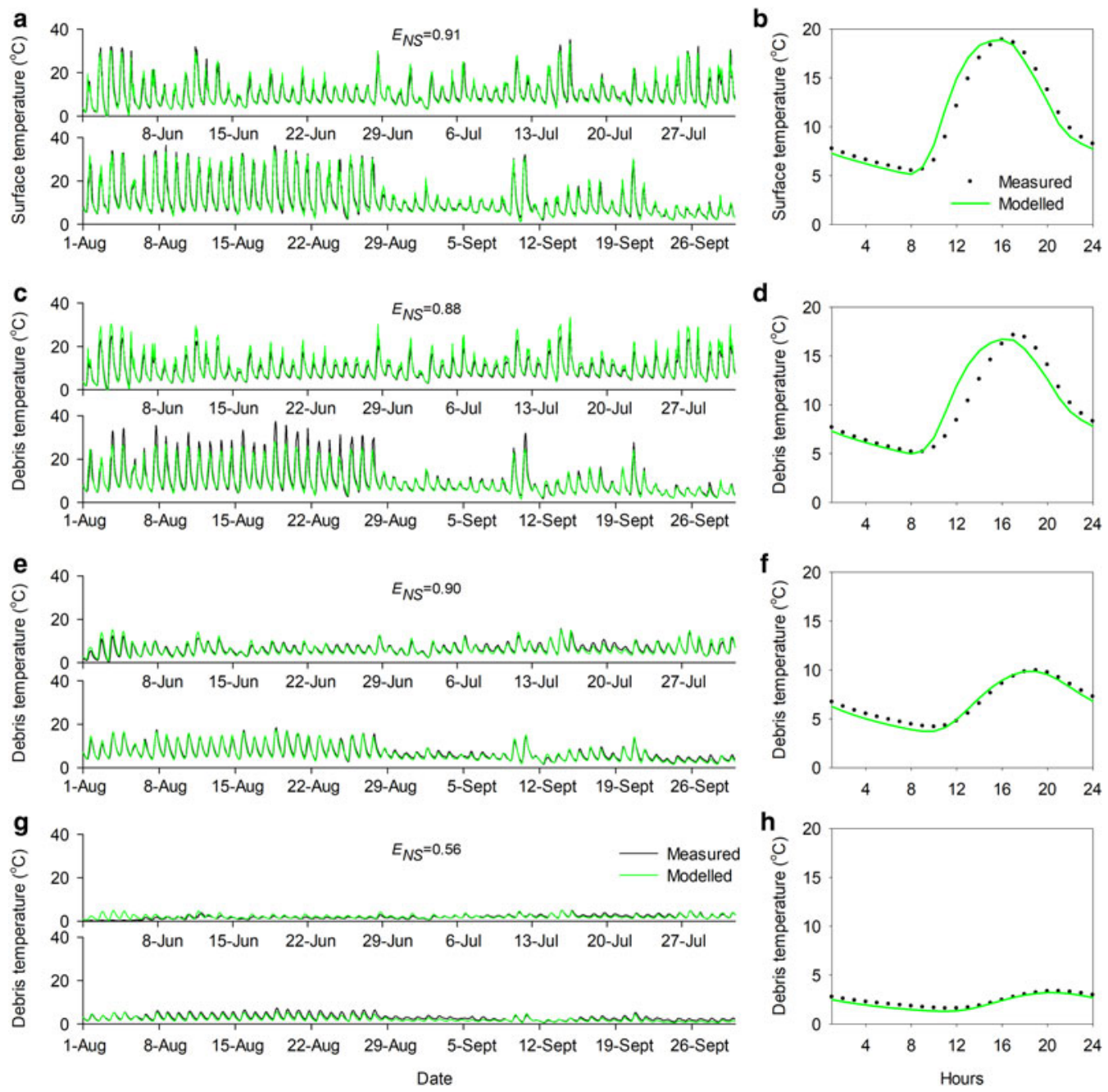

Fig. 4. Simulated and measured hourly and mean diurnal surface temperature $(a, b)$ and debris internal temperature at $5 \mathrm{~cm}(\mathrm{c}, \mathrm{d}), 10 \mathrm{~cm}(\mathrm{e}, \mathrm{f})$ and $20 \mathrm{~cm}$ depth $(\mathrm{g}, \mathrm{h})$ near the AWS on the $24 \mathrm{~K}$ Glacier, $E_{N S}$ is the Nash-Sutcliffe model efficiency coefficient.

ice surface increased continuously until early morning due to water condensation by the cooled surface. The mean diurnal amplitudes are 23.1 and $12.6 \%$ for Parlung No. 4 Glacier and $24 \mathrm{~K}$ Glacier, respectively. During clear-sky weather conditions, both glaciers exhibit significant diurnal fluctuations with the mean amplitude being $26.0 \%$ for Parlung No. 4 Glacier and $29.4 \%$ for $24 \mathrm{~K}$ Glacier (Fig. $7 \mathrm{~b}$ and Table 3). In contrast, the mean diurnal amplitudes during the overcast conditions were greatly reduced, with values of $18 \%$ at Parlung No. 4 Glacier and $6.2 \%$ at $24 \mathrm{~K}$ Glacier. Indeed, the continuous rainfall at $24 \mathrm{~K}$ Glacier (see in Section 4.1.4) provided abundant moisture and thus contributed to the lesser diurnal amplitude of relative humidity during the overcast and rainy days. In contrast, the debris surface warmed the above surface air by convective and radiative heating in clear-sky conditions, thus contributing to the significant diurnal fluctuations of relative humidity.

\subsubsection{Incoming shortwave $\left(\mathrm{S}_{i n}\right)$ and longwave $\left(\mathrm{L}_{i n}\right)$ radiation}

Both glaciers received approximately the same mean $S_{\text {in }}$ during the observational period $\left(\sim 213.0 \mathrm{~W} \mathrm{~m}^{-2}\right)$ and exhibit similar diurnal variations (Fig. 6c). However, there were obvious differences in the pattern of daily variations (Fig. 5c) and correlation is moderate $(r=0.23, p<0.05)$.
During the whole observational period, the daily mean $S_{\text {in }}$ at $24 \mathrm{~K}$ Glacier was generally lower than at Parlung No. 4 Glacier, except for August. The mean $S_{\text {in }}$ in August at $24 \mathrm{~K}$ Glacier was $301.7 \mathrm{~W} \mathrm{~m}^{-2}, \sim 97 \mathrm{~W} \mathrm{~m}^{-2}$ higher than the corresponding value at Parlung No. 4 Glacier. This reflects the different cloud and moisture conditions between the two glaciers (Fig. 5b and Table 2). The daily mean cloudiness was estimated to be $\sim 0.69$ at Parlung No. 4 Glacier but 0.75 at $24 \mathrm{~K}$ Glacier. The daily mean $S_{\text {in }}$ at $24 \mathrm{~K}$ Glacier exhibited high seasonal variability, with Std dev.s of 58.9 and $112.9 \mathrm{~W}$ $\mathrm{m}^{-2}$ during the whole observational period for Parlung No. 4 Glacier and $24 \mathrm{~K}$ Glacier, respectively. During the overcast conditions, the difference in mean $S_{\text {in }}$ between the two glaciated regions was limited $\left(\sim 17 \mathrm{~W} \mathrm{~m}^{-2}\right)$ and their diurnal fluctuations had a similar form. In contrast, the mean value of $S_{\text {in }}$ during clear-sky weather conditions at $24 \mathrm{~K}$ Glacier was $\sim 130 \mathrm{~W} \mathrm{~m}^{-2}$ greater than that at Parlung No. 4 Glacier and the peak in $S_{\text {in }}$ occurred $2 \mathrm{~h}$ earlier at $24 \mathrm{~K}$ Glacier (Fig. 7c and Table 3). This indicates that there were distinct differences in atmospheric transmissivities characteristics (e.g. water vapor, cloud thickness) between these two different climatic regimes during the clear-sky conditions.

The mean $L_{\text {in }}$ values were $\sim 303$ and $345 \mathrm{~W} \mathrm{~m}^{-2}$ for Parlung No. 4 Glacier and $24 \mathrm{~K}$ Glacier, respectively (Fig. 5d), with a strong correlation between the two glaciers $(r=0.80, p<0.01)$. The larger $L_{\text {in }}$ at $24 \mathrm{~K}$ Glacier is a result 


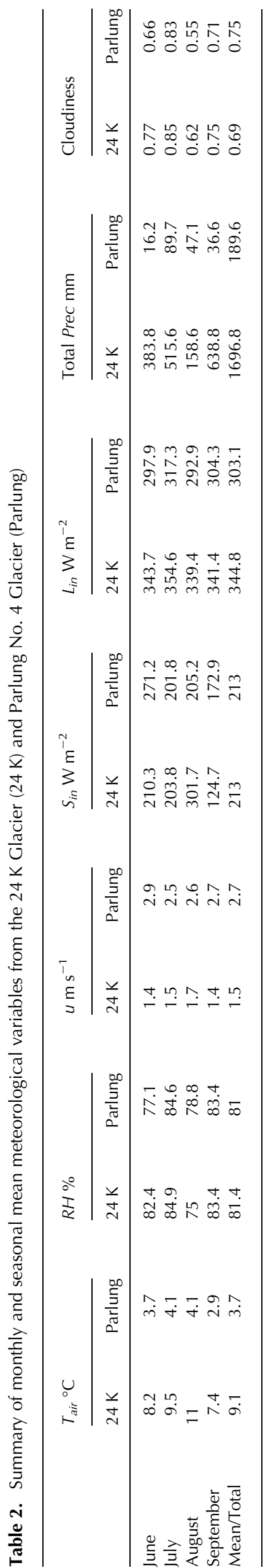

of the warmer and cloudier weather. The temporal variability of $L_{\text {in }}$ was generally similar to that of the relative humidity. The correlation coefficients between $L_{\text {in }}$ and relative humidity are 0.86 and 0.79 for Parlung No. 4 Glacier and $24 \mathrm{~K}$ Glacier, respectively $(p<0.01)$. The diurnal patterns of $L_{\text {in }}$ between the two glaciers exhibit obvious phase differences, with the maximum values at 14:00 at Parlung No. 4 Glacier but at 16:00 at $24 \mathrm{~K}$ Glacier (Fig. 6d). Compared with the high variability of $S_{\text {in }}$ the relatively low Std dev.s of daily mean $L_{\text {in }}\left(14.8 \mathrm{vs} 20.9 \mathrm{~W} \mathrm{~m}^{-2}\right)$, and a lower degree of diurnal variations in both clear-sky and overcast conditions (Fig. 7c), indicated the lesser role of $L_{\text {in }}$ in controlling both daily and diurnal variations in melting energy during the 2016 ablation season at the two glaciers.

\subsubsection{Wind direction and speed}

Despite the lack of wind direction data at Parlung No. 4 Glacier due to an instrumental problem in 2016, a previous study indicated that persistent katabatic (glacier) winds control the near-surface air flow (Yang and others, 2011). For $24 \mathrm{~K}$ Glacier, the dominant wind direction ranged from $310^{\circ}$ to $330^{\circ}$, corresponding to the glacier flow path (the orientation of the glacier's central axis is $\sim 310^{\circ}$ ) and indicating that katabatic winds were also common at this debriscovered glacier.

Although both glaciers are influenced by katabatic winds, local factors including glacier size, length and surface conditions (melting snow/ice and debris cover), contribute to the different magnitudes of katabatic wind. The wind speeds were on average 1.8 times higher at Parlung No. 4 Glacier (Fig. 5e and Table 2); in addition, they were more variable with a Std dev. of $0.69 \mathrm{~m} \mathrm{~s}^{-1}$, in comparison with $0.24 \mathrm{~m} \mathrm{~s}^{-1}$ at $24 \mathrm{~K}$ Glacier. The wind speeds at both glaciers did not exhibit significant seasonal trends over the observational period. The correlation coefficient in mean daily wind speeds was modest $(r=0.33, p<0.05)$. There was a significant difference during the daytime when katabatic winds were common at Parlung No. 4 Glacier. At Parlung No. 4 Glacier, the wind speed increased dramatically when the sun rose at $\sim 09: 00$, reached a maximum at 18:00, and then decreased; the diurnal amplitude was $3.5 \mathrm{~m} \mathrm{~s}^{-1}$ (Fig. 6e). In contrast, the wind speed at the debris-covered $24 \mathrm{~K}$ Glacier was characterized by lower diurnal variability, with a mean amplitude of $0.78 \mathrm{~m} \mathrm{~s}^{-1}$. During clear-sky conditions, the mean wind speed $\left(2.34 \mathrm{~m} \mathrm{~s}^{-1}\right)$ at Parlung No. 4 Glacier was $\sim 0.58 \mathrm{~m} \mathrm{~s}^{-1}$ greater than that in overcast conditions $\left(2.92 \mathrm{~m} \mathrm{~s}^{-1}\right)$, while it was slightly increased from 1.57 to $1.67 \mathrm{~m} \mathrm{~s}^{-1}$ at $24 \mathrm{~K}$ Glacier (Table 3 ). Wind speed in the afternoon during clear-sky conditions was significantly larger than that during overcast conditions at Parlung No. 4 Glacier, which shows that under clear sky conditions the katabatic wind is much stronger (Fig. $7 \mathrm{~d}$ ). In contrast, there were limited changes in both mean wind speed and diurnal amplitude at the debris-covered $24 \mathrm{~K}$ Glacier between clear-sky and overcast conditions.

\subsubsection{Precipitation}

The most striking difference between the two glaciers was in precipitation (Fig. 5f). The total precipitation amount during the observational period at $24 \mathrm{~K}$ Glacier was approximately nine times that at Parlung No. 4 Glacier (1696.8 vs $189.6 \mathrm{~mm})$. The continuous and abundant precipitation at $24 \mathrm{~K}$ Glacier was punctuated by an episode of lower 

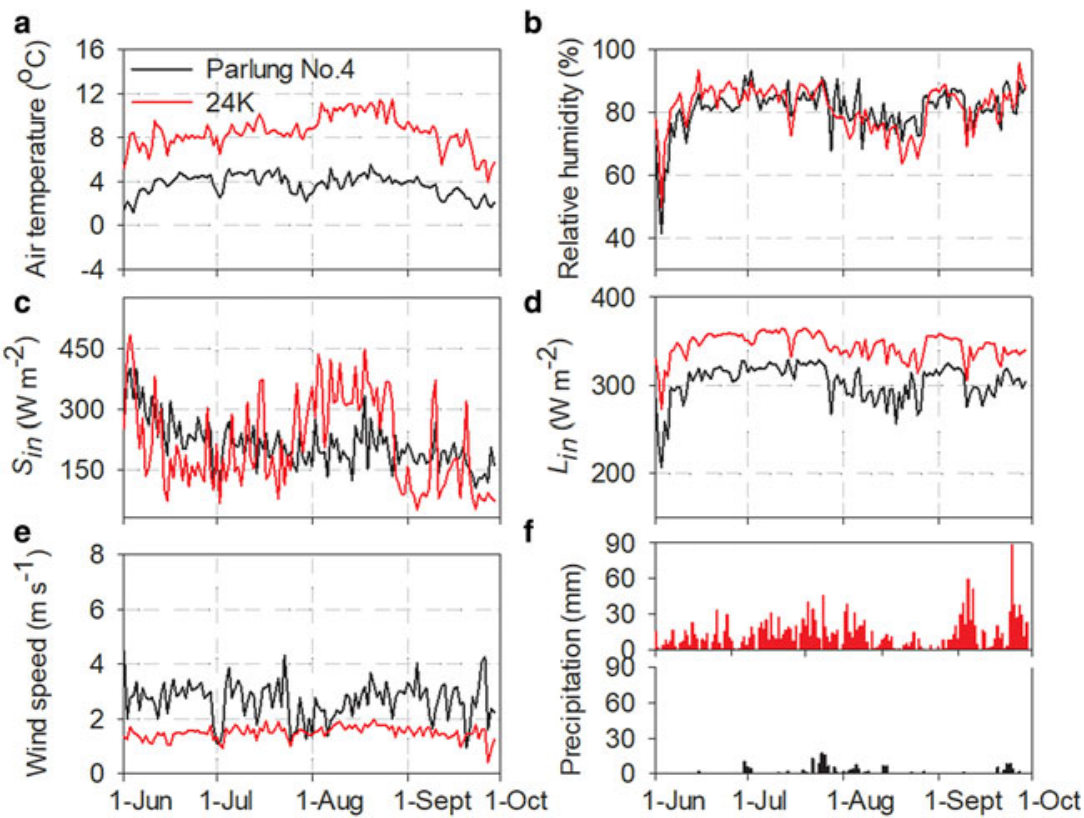

Fig. 5. Comparison of mean daily meteorological data, including air temperature (a), relative humidity (b), incoming shortwave (c) and longwave radiation (d), wind speed (e) and precipitation (d), during the 2016 ablation season (June-September) between the Parlung No. 4 and $24 \mathrm{~K}$ Glaciers.

precipitation in August. The maximum monthly precipitation totals were concentrated in September $(638.8 \mathrm{~mm})$ at $24 \mathrm{~K}$ Glacier and in July $(89.7 \mathrm{~mm})$ at Parlung No. 4 Glacier, while the minimum totals were in August $(158.6 \mathrm{~mm})$ and June $(16.2 \mathrm{~mm})$. Precipitation during nighttime (21:00-8:00) accounted for $\sim 60$ and $67 \%$ for the precipitation at $24 \mathrm{~K}$ Glacier and Parlung No. 4 Glacier, respectively (Fig. 6f). Figure 8 also compares precipitation intensity between the two glaciers. The most common precipitation intensity was
8-16 $\mathrm{mm} \mathrm{d}^{-1}$ and occasional strong rainfall storms (>60 mm $\mathrm{d}^{-1}$ ) were recorded at $24 \mathrm{~K}$ Glacier; on 23 September the maximum daily total precipitation even exceeded $88 \mathrm{~mm}$. In contrast, at Parlung No. 4 Glacier, 98 of the 122 days from June to September were rain-free or experienced little precipitation $\left(<2.0 \mathrm{~mm} \mathrm{~d}^{-1}\right)$.

Such large differences can be partly explained by the complex topography and terrain exposure. Geographically, the east-west Gangrigabu Mountain plays a critical role as a
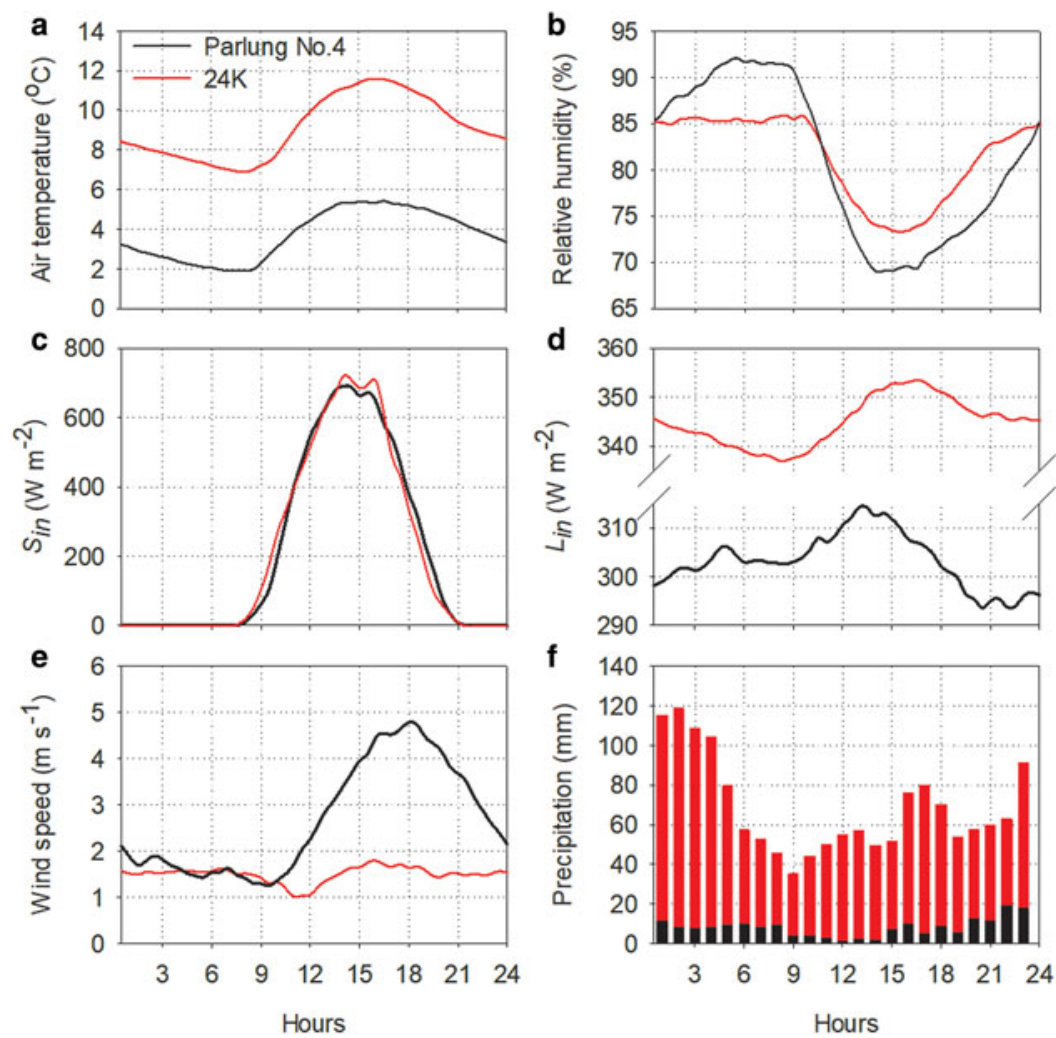

Fig. 6. Comparison of the diurnal variation of meteorological data between the Parlung No. 4 and $24 \mathrm{~K}$ Glaciers. 

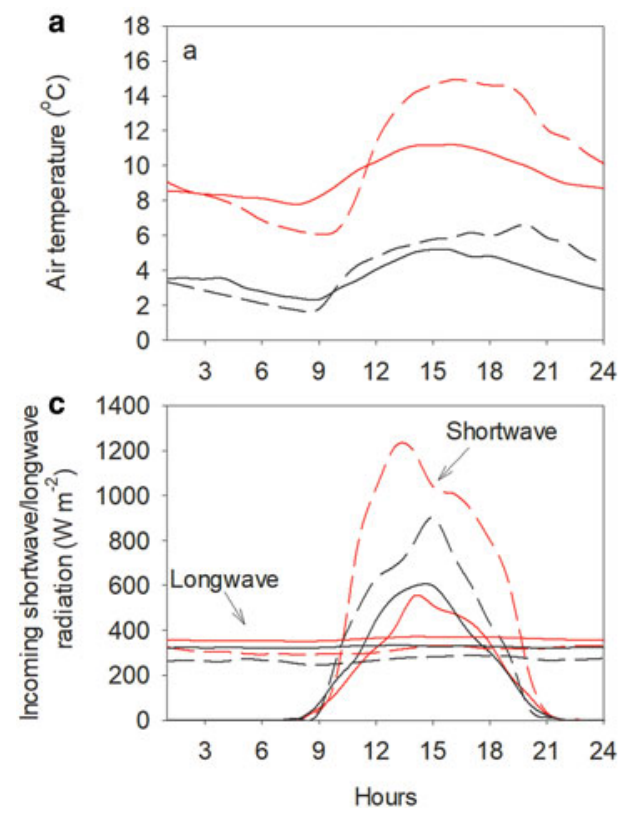
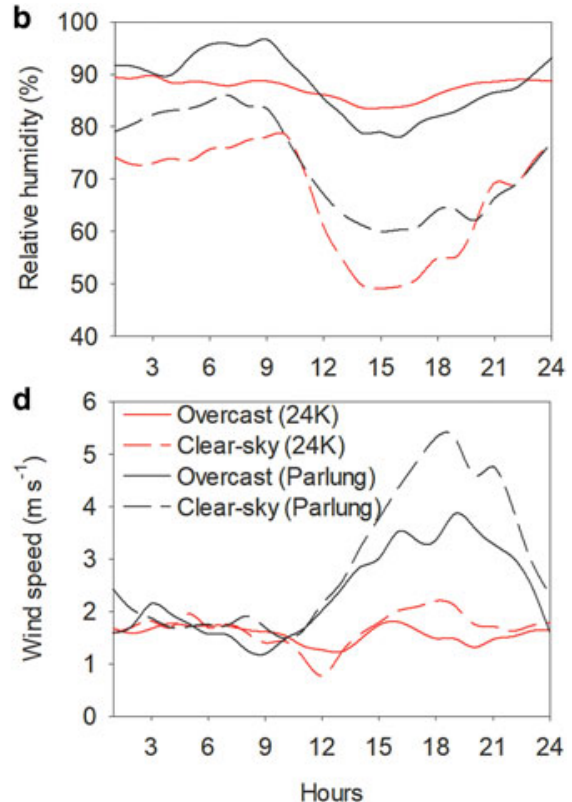

Fig. 7. Comparison of the diurnal variation of meteorological data for both Parlung No. 4 Glacier (Parlung) and 24 K Glacier (24 K) between clear-sky conditions and overcast conditions.

barrier for precipitation (Fig. 1); $24 \mathrm{~K}$ Glacier is located on the windward side, whereas Parlung No. 4 Glacier is located on the leeward side. In addition, $24 \mathrm{~K}$ Glacier is closer to the Brahmaputra Grand Canyon, which acts as a corridor for long-range moisture transfer (He and others, 2007); moreover, the ridge of eastern Gangrigabu Mountain is lower in the vicinity of $24 \mathrm{~K}$ Glacier. Therefore, the windward $24 \mathrm{~K}$ Glacier received exceptionally heavy orographic rainfall, whereas much less precipitation fell on the leeward Parlung No. 4 Glacier. This high degree of precipitation variability means that knowledge of the horizontal and altitudinal distribution of precipitation is essential for regional glaciological and hydrological studies throughout the mountainous southeastern Tibetan Plateau region.

\subsection{Surface energy balance comparison between debris-free and debris-covered glaciers}

Figure 9 illustrates the mean daily and diurnal cycles of surface energy fluxes near the AWSs on the two glaciers

Table 3. Summary of mean meteorological variables and energy fluxes in overcast and clear-sky conditions at $24 \mathrm{~K}$ Glacier and Parlung No. 4 Glacier

\begin{tabular}{|c|c|c|c|c|}
\hline \multirow[t]{2}{*}{ Variables } & \multicolumn{2}{|c|}{ Parlung No. 4 Glacier } & \multicolumn{2}{|c|}{24 K Glacier } \\
\hline & Overcast & Clear-sky & Overcast & Clear-sky \\
\hline$T_{\text {air }}\left({ }^{\circ} \mathrm{C}\right)$ & 3.7 & 4.2 & 9.4 & 10.5 \\
\hline$R H(\%)$ & 88.1 & 72.7 & 87.4 & 66.7 \\
\hline$u\left(\mathrm{~m} \mathrm{~s}^{-1}\right)$ & 2.3 & 2.9 & 1.6 & 1.7 \\
\hline Surface albedo & 0.25 & 0.23 & 0.05 & 0.07 \\
\hline$S_{\text {in }}\left(\mathrm{W} \mathrm{m}^{-2}\right)$ & 176.4 & 251.5 & 159.2 & 381.4 \\
\hline$S_{\text {out }}\left(\mathrm{W} \mathrm{m}^{-2}\right)$ & -43.5 & -58.9 & -7.8 & -25.1 \\
\hline$L_{\text {in }}\left(\mathrm{W} \mathrm{m}^{-2}\right)$ & 325.5 & 265.4 & 360.2 & 312.2 \\
\hline$L_{\text {out }}\left(\mathrm{W} \mathrm{m}^{-2}\right)$ & -318.1 & -315.7 & -365.1 & -392.0 \\
\hline$H_{\text {sen }}\left(\mathrm{W} \mathrm{m}^{-2}\right)$ & 12.9 & 21.1 & -41.2 & -194.7 \\
\hline$H_{\text {lat }}\left(\mathrm{W} \mathrm{m}^{-2}\right)$ & 5.6 & -1.0 & -49.7 & -8.2 \\
\hline$G_{\mathrm{p}} / G_{\mathrm{i}}\left(\mathrm{W} \mathrm{m}^{-2}\right)$ & $\begin{array}{l}0.33 \\
(-2.4)\end{array}$ & $\begin{array}{l}0.05 \\
(-2.6)\end{array}$ & -0.22 & -0.05 \\
\hline$Q_{\text {melting }} / G_{\mathrm{d}}\left(\mathrm{W} \mathrm{m}^{-2}\right)$ & -156.7 & -159.9 & -55.4 & -73.6 \\
\hline
\end{tabular}

during the period from June to September 2016. For Parlung No. 4 Glacier the main energy contribution was net shortwave radiation $\left(S_{\text {net }}:+142.6 \mathrm{~W} \mathrm{~m}^{-2}\right)$, followed by the sensible heat flux $\left(H_{\text {sen }}:+17.1 \mathrm{~W} \mathrm{~m}^{-2}\right)$. A minor release of heat by water vapor condensation contributed to the surface melting $\left(H_{\text {lat }}:+1.5 \mathrm{~W} \mathrm{~m}^{-2}\right)$. The net longwave radiation acts as a heat sink $\left(L_{\text {net }}:-13.0 \mathrm{~W} \mathrm{~m}^{-2}\right)$ and the subsurface heat flux $G_{\mathrm{i}}$ is $<-2.4 \mathrm{~W} \mathrm{~m}^{-2}$ and the sensible heat by precipitation $G_{p}$ is negligible $\left(+0.07 \mathrm{~W} \mathrm{~m}^{-2}\right)$. Most of the surface energy was used for surface snow/ice melting $\left(Q_{\text {melting: }}-145.9 \mathrm{~W} \mathrm{~m}^{-2}\right)$. Overall, the $S_{\text {net }}$ was mirrored by $Q_{\text {melting }}$ at both daily and diurnal scales. The hourly melting energy reached a maximum at $\sim 15: 00$, which corresponded to the maximum hourly $S_{i n}$.

For the debris-covered surface at $24 \mathrm{~K}$ Glacier, mean energy supply by precipitation $\left(\sim+0.1 \mathrm{~W} \mathrm{~m}^{-2}\right)$ was negligible compared with the other fluxes. The $S_{\text {net }}$ was assumed to be the only net energy input $\left(+201 \mathrm{~W} \mathrm{~m}^{-2}\right)$ during the ablation season. The other energy components were all energy sinks, accounting for $-87.1 \mathrm{~W} \mathrm{~m}^{-2}$ by $H_{\text {sen, }}-25.2 \mathrm{~W} \mathrm{~m}^{-2}$ by $L_{\text {net }},-25.0 \mathrm{~W} \mathrm{~m}^{-2}$ by $H_{\text {lat }}$ (evaporative) and $-63.8 \mathrm{~W} \mathrm{~m}^{-2}$ by $G_{\mathrm{d}}$. Significant negative correlations between $S_{\text {net }}$ and $H_{\text {sen }}$ were observed during the observational period $(r=0.97, p<0.01)$. These results indicate that the debris surface was heated by $S_{\text {in }}$ and the corresponding surface temperature rise resulted in increased energy output mainly through $H_{\text {sen }}$ (Brock and others, 2010). With regard to the diurnal magnitude of each flux, maximum $G_{d}$ occurred at 11:00-12:00 at the debris surface on $24 \mathrm{~K}$ Glacier. The DEB model showed that thermal conduction required $10-11 \mathrm{~h}$ to result in peak melt beneath the $25 \mathrm{~cm}$ thick debris layer.

In spite of the same mean $S_{\text {in }}$ during the observational period $\left(\sim 213 \mathrm{~W} \mathrm{~m}^{-2}\right)$ at the two glaciers, the lower mean surface albedo (0.05) due to the dark debris material at $24 \mathrm{~K}$ Glacier contributed to $\sim 58 \mathrm{~W} \mathrm{~m}^{-2}$ more solar energy absorbed by the debris surface than that at the debris-free Parlung No. 4 Glacier with a mean surface albedo of 0.32 (Fig. 9 and Table 4). In addition, due to the more humid and warm air at $24 \mathrm{~K}$ Glacier, the $L_{\text {in }}$ was $\sim 42 \mathrm{~W} \mathrm{~m}^{-2}$ 

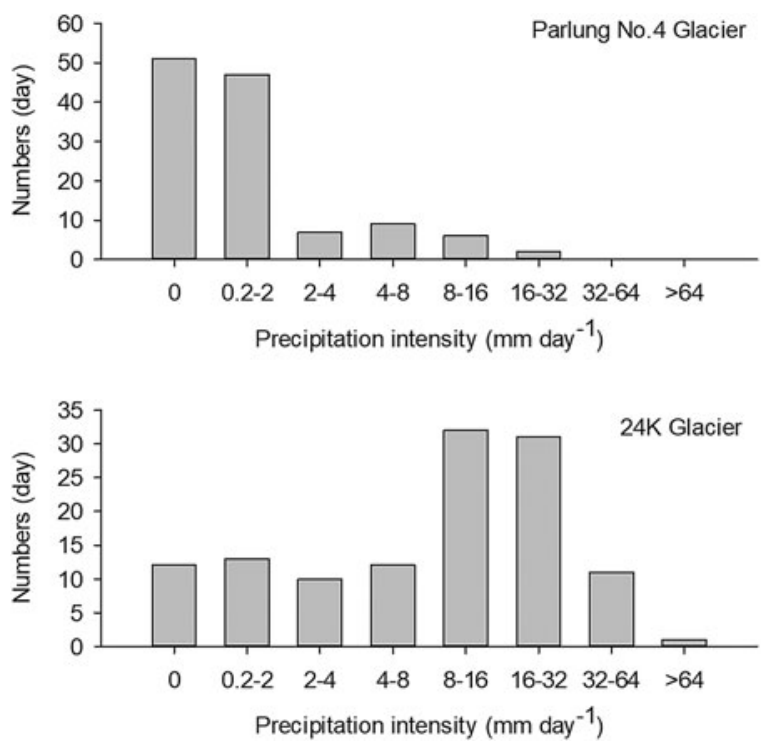

Fig. 8. Comparison of precipitation intensity between the Parlung No. 4 and $24 \mathrm{~K}$ Glaciers from June to September.

higher; energy supply from the atmosphere to the debris surface was therefore significantly greater in the vicinity of $24 \mathrm{~K}$ Glacier. However, the energy supply $\left(S_{\text {net }}+L_{\text {in }}\right.$ : $545.8 \mathrm{~W} \mathrm{~m}^{-2}$ ) was mainly consumed by heating the debris surface, which led to higher surface temperatures than air temperatures (Fig. 10). Most of the energy at $24 \mathrm{~K}$ Glacier was consumed by $L_{\text {out, }} H_{\text {sen, }}$ and $H_{\text {lat }}$. The $G_{\mathrm{d}}$ was restricted to only $-63.8 \mathrm{~W} \mathrm{~m}^{-2}$ at the AWS location. The debris cover, therefore, provided effective insulation for the underlying ice by returning the energy supply to the atmosphere as longwave radiation, sensible heat flux and evaporation. In contrast, due to the upper limit of the temperature $\left(0^{\circ} \mathrm{C}\right)$ of the snow/ice surface, the air temperature during the ablation season was generally higher than the surface temperature at Parlung No. 4 Glacier (Fig. 10). The mean value of $L_{\text {out }}$ on the debris-free surface remained at constant values of $-316.1 \mathrm{~W} \mathrm{~m}^{-2}$; however, the energy supply $\left(S_{\text {net }}+L_{\text {in }}+\right.$ $\left.H_{\text {sen }}+H_{\text {lat }}\right)$ was as much as $461.8 \mathrm{~W} \mathrm{~m}^{-2}$, leading to a residual energy of $\sim 145.9 \mathrm{~W} \mathrm{~m}^{-2}$ for snow/ice melting. Thus, the existence of the debris layer not only resulted in a different surface albedo (0.05 vs 0.32$)$, but it also resulted in differences in energy fluxes, particularly for the outgoing longwave radiation and turbulent fluxes between the debris-free and debris-covered glacier. Consequently, the calculated daily melt rates were $35.2 \mathrm{~mm} \mathrm{~d}^{-1}$ at Parlung No. 4 Glacier, in comparison with $19.5 \mathrm{~mm} \mathrm{~d}^{-1}$ at $24 \mathrm{~K}$ Glacier.

\section{DISCUSSION}

\subsection{Comparison of the energy fluxes under different weather conditions}

To investigate the melting magnitudes and their controlling energy fluxes under different extreme weather conditions, the energy fluxes between clear-sky and overcast weather conditions were compared between Parlung No.4 Glacier and $24 \mathrm{~K}$ Glacier (Fig. 11). Table 3 lists in detail the values of energy fluxes under different weather conditions. It is
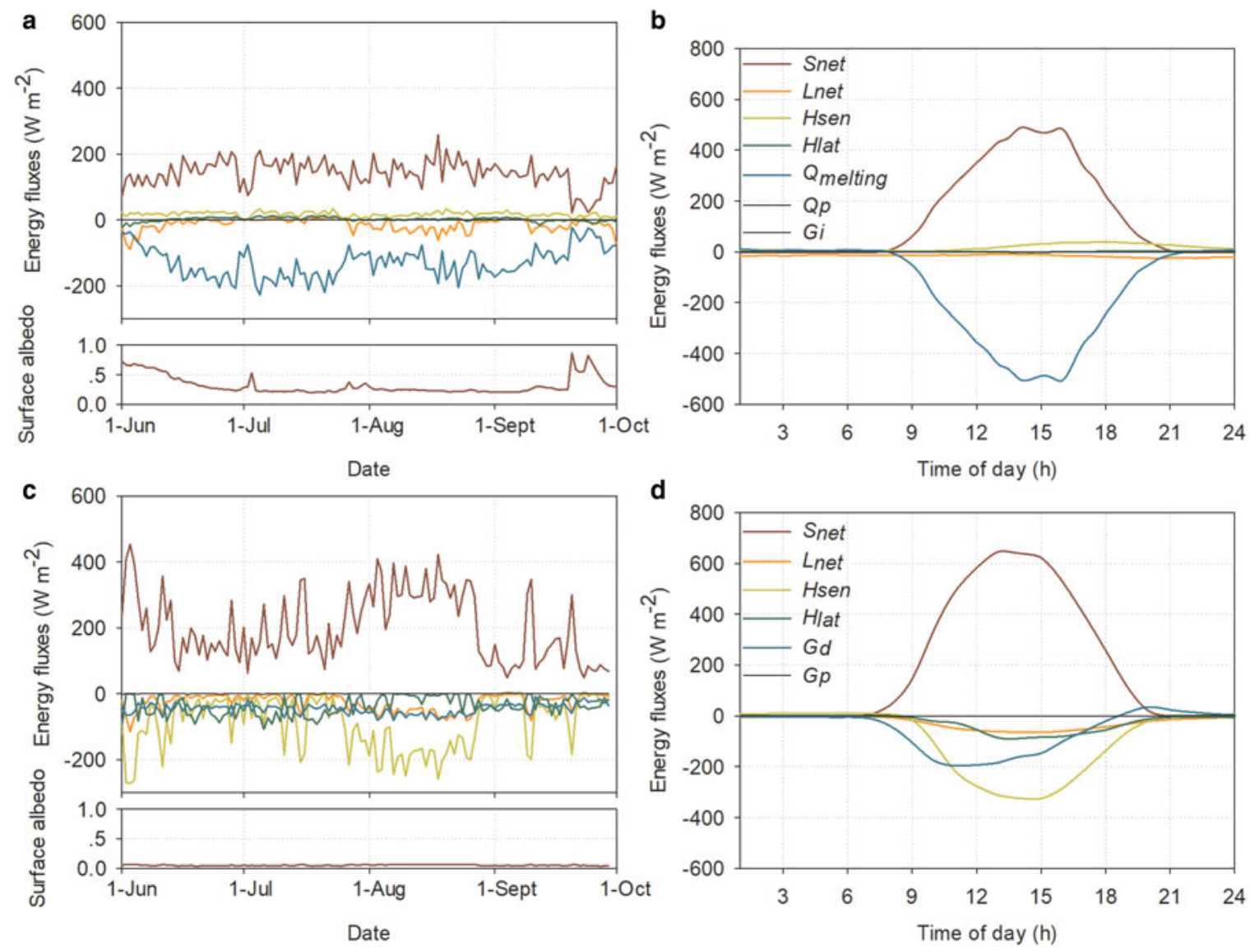

Fig. 9. Daily mean and diurnal cycle of surface energy fluxes near the AWSs on the debris-free Parlung No. 4 Glacier (a, b) and debris-covered $24 \mathrm{~K}$ Glacier (c, d), together with daily fluctuations in surface albedo. 
Table 4. Mean meteorological and energy fluxes at the debris-free Parlung No. 4 Glacier and debris-covered 24 K Glacier in 2016 (1 June-29 September), together with available comparative data for the Parlung No. 4 Glacier in 2009 (21 May-8 September, Yang and others, 2011) and the debris-covered Miage Glacier, Italy in 2005 (22 June-2 September, Brock and others, 2010)

\begin{tabular}{|c|c|c|c|c|}
\hline Variables & $\begin{array}{l}\text { Parlung } \\
\text { No. } 42016\end{array}$ & $\begin{array}{l}\text { Parlung } \\
\text { No. } 42009\end{array}$ & $\begin{array}{l}24 \mathrm{~K} \\
\text { Glacier } \\
2016\end{array}$ & $\begin{array}{l}\text { Miage } \\
\text { Glacier* } \\
2005\end{array}$ \\
\hline Elevation (m a.s.l.) & 4800 & 4800 & 3900 & 2030 \\
\hline Debris thickness $(\mathrm{cm})$ & 0 & 0 & 25 & 23 \\
\hline $2 \mathrm{~m}$ air temperature $\left({ }^{\circ} \mathrm{C}\right)$ & 3.7 & 3.7 & 9.1 & 10.7 \\
\hline 2 m relative humidity $(\%)$ & 81.0 & 78.5 & 81.4 & 66 \\
\hline $2 \mathrm{~m}$ wind speed $\left(\mathrm{m} \mathrm{s}^{-1}\right)$ & 2.7 & 3.2 & 1.5 & 2.6 \\
\hline Precipitation (mm) & 190 & 120 & 1697 & 274 \\
\hline$S_{\text {in }}\left(\mathrm{W} \mathrm{m}^{-2}\right)$ & 213.0 & 242 & 213.0 & 250 \\
\hline Albedo & 0.32 & 0.29 & 0.05 & 0.13 \\
\hline$S_{\text {net }}\left(\mathrm{W} \mathrm{m}^{-2}\right)$ & 142.6 & 170 & 201.0 & 219 \\
\hline$L_{\text {in }}\left(\mathrm{W} \mathrm{m}^{-2}\right)$ & 303.1 & 295 & 344.8 & 299 \\
\hline$L_{\text {out }}\left(\mathrm{W} \mathrm{m}^{-2}\right)$ & -316.1 & -315 & -370.0 & -369 \\
\hline$L_{\text {net }}\left(\mathrm{W} \mathrm{m}^{-2}\right)$ & -13.0 & -20 & -25.2 & -70 \\
\hline$H_{\text {sen }}\left(\mathrm{W} \mathrm{m}^{-2}\right)$ & 17.1 & 28 & -87.1 & -75 \\
\hline$H_{\text {lat }}\left(\mathrm{W} \mathrm{m}^{-2}\right)$ & 1.5 & -1 & -25.0 & -14 \\
\hline$G_{\mathrm{p}} / G_{\mathrm{i}}\left(\mathrm{W} \mathrm{m}^{-2}\right)$ & $\begin{array}{l}0.07 / \\
(-2.4)\end{array}$ & $-/(-1)$ & 0.1 & - \\
\hline$Q_{\text {melting }} / G_{\mathrm{d}}\left(\mathrm{W} \mathrm{m}^{-2}\right)$ & -145.9 & -175 & -63.8 & -57 \\
\hline
\end{tabular}

* The Miage Glacier Data are for the lower AWS at $2030 \mathrm{~m}$ a.s.l; - represents no data available.

clear that for Parlung No. 4 Glacier, a large difference in surface energy balance occurs in $S_{\text {in }}$ and $L_{\text {in }}$. Overall, compared with clear-sky conditions, the decrease in $S_{\text {in }}$ at Parlung No. 4 Glacier was mainly compensated by the increased $L_{\text {in }}$ supply in overcast conditions. Such radiation compensation has been also recorded in many temperate glaciated regions (e.g. Conway and Cullen, 2016). In
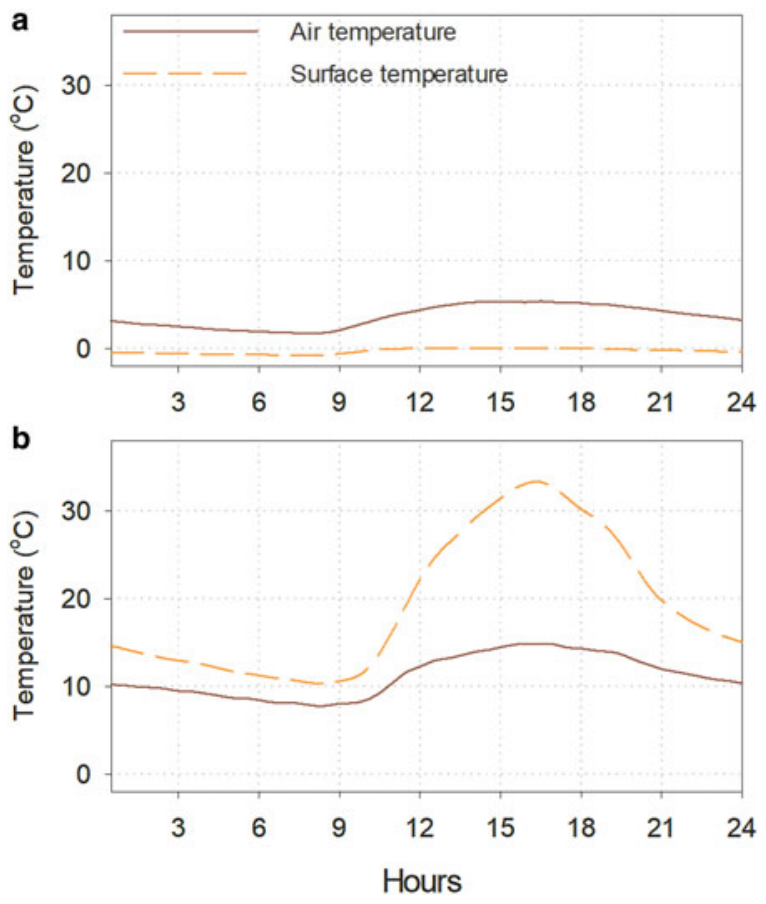

Fig. 10. Mean diurnal variations of 2-m air temperature and surface temperature at the snow/ice surface on the Parlung No. 4 Glacier (a) and on the debris-covered surface of the $24 \mathrm{~K}$ Glacier (b).

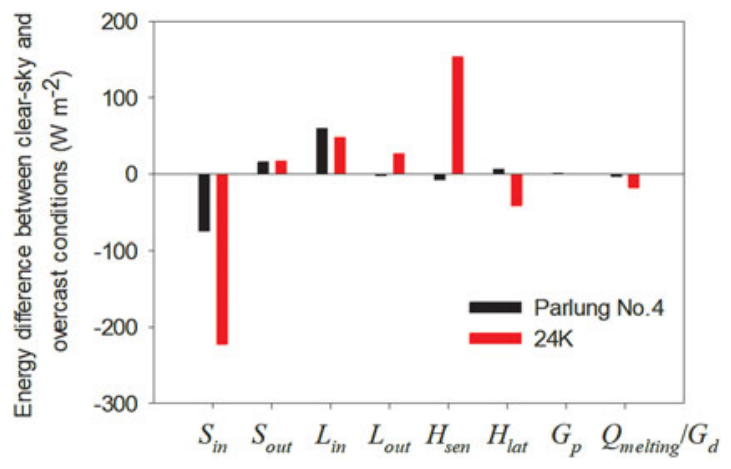

Fig. 11. Differences in surface energy fluxes between overcast and clear-sky conditions at Parlung No. 4 Glacier and 24 K Glacier.

addition, the decreased $H_{\text {sen }}$ was to some extent balanced by the increased $H_{\text {lat }}$ release by water condensation in the overcast conditions. Consequently, the surface energy for melting during overcast conditions was only $3.3 \mathrm{~W} \mathrm{~m}^{-2}$ lower than that in clear-sky conditions and average daily melt rates were of a similar magnitude between overcast and clear-sky conditions.

In contrast, the energy discrepancy between overcast and clear-sky conditions exhibits a different pattern at the debriscoved $24 \mathrm{~K}$ Glacier. The difference in mean $S_{\text {in }}$ between these two contrasting weather conditions was $\sim 222 \mathrm{~W} \mathrm{~m}^{-2}$. In contrast to the radiation compensation at Parlung No.4 Glacier, the decrease in $S_{\text {in }}$ in overcast conditions was significantly compensated by the weakened sensible heat loss, rather than the increased $L_{\text {in }}$ (Table 3). Thus there is a $S_{\text {in }}-$ $H_{\text {sen }}$ compensation pattern in the case of the debris-covered $24 \mathrm{~K}$ Glacier. In addition, due to the wetter conditions when the sky was overcast, the energy consumption by surface evaporation was also greater than in clear-sky conditions. Overall, the surface energy for melting in overcast conditions was $18 \mathrm{~W} \mathrm{~m}^{-2}$ less than that in clear-sky conditions. This comparison, on the one hand, reveals different response patterns of surface energy fluxes to weather conditions. On the other hand, it indicates that debris-covered glaciers in relatively warm and humid climatic regimes, similar to $24 \mathrm{~K}$ Glacier, are more sensitive to the sky conditions, which affected the relevant energy fluxes. This finding raises the important possibility that the evolution of the Indian summer monsoon would result in different responses of glacier energy balance and mass loss between debris-free and debris-covered glaciers in the monsoon-influenced Tibetan Plateau (e.g. Conway and Cullen, 2016; Yang and others, 2016).

\subsection{Comparison of the energy fluxes with those of other studies}

The surface energy fluxes during the 2016 ablation season at the debris-free Parlung No. 4 Glacier were compared with the available results for the 2009 ablation season in order to clarify the dominant fluxes controlling the annual changes of surface melting in the ablation zone (Table 4). The energy fluxes between the two ablation seasons exhibit similar magnitudes and patterns, reflecting the basic energy characteristics in the ablation zone of the debris-free glaciers in the southeastern Tibetan Plateau. However, the surface energy for melting $\left(Q_{\text {melting }}\right)$ during the 2016 ablation season was $\sim 29 \mathrm{~W} \mathrm{~m}^{-2}$ less than during 2009, in spite of 
the same mean air temperature $\left(3.7^{\circ} \mathrm{C}\right)$. It is noteworthy that the total amount of precipitation was $\sim 58 \%$ greater during the 2016 ablation season. The more humid air and cloudier conditions, therefore, resulted in a substantial reduction in $S_{\text {in }}\left(-29 \mathrm{~W} \mathrm{~m}^{-2}\right)$. However, the mean atmospheric conditions during the 2016 summer season were not as humid/cloudy as that in the extreme overcast conditions in Section 5.1 (e.g. relative humidity: 81.0 vs $88.1 \%$ ), while there was a lesser increase in $L_{\text {in }}\left(+8 \mathrm{~W} \mathrm{~m}^{-2}\right)$ and the decrease in $S_{\text {in }}$ was not greatly compensated by the increased $L_{\text {in }}$ supply. In addition, the surface albedo in 2016 was higher than that in 2009, partly contributing to the lower absorption of solar radiation at the snow/ice surface. Moreover, due to the weaker katabatic wind $\left(3.2 \mathrm{~m} \mathrm{~s}^{-1}\right.$ in $2009 \mathrm{vs} 2.7 \mathrm{~m} \mathrm{~s}^{-1}$ in 2016), $H_{\text {sen }}$ decreased from +28 to $+17 \mathrm{~W} \mathrm{~m}^{-2}$. Both $L_{\text {out }}$ and $H_{\text {lat }}$ exhibited limited differences between the two ablation seasons. Overall, the reduced $Q_{\text {melting }}$ in the 2016 ablation season was mainly attributed to the significant decrease in both $S_{\text {in }}$ and $H_{\text {sen. }}$. These comparisons of the energy components between the two different ablation seasons and the two extreme weather conditions in Section 5.1 indicate that the magnitudes of snow/ice melting were indeed linked to the variation of atmospheric conditions (e.g. cloud and water vapor), which control the magnitude of surface energy fluxes, and further demonstrates that the Indian summer monsoon significantly influences the glacier energy balance and mass loss in the southeastern Tibetan Plateau (Yang and others, 2016).

Few detailed energy-balance results are available for debris-covered glaciers. However, the published results (e.g., Takeuchi and others, 2000; Brock and others, 2007, 2010) indicate that the net surface energy balance of the thick debris surface was supplied solely by solar radiation but was consumed by $H_{\text {sen, }} L_{\text {out }}, H_{\text {lat }}$ and $G_{\mathrm{d}}$. A detailed meteorological and energy-balance study of a debris-covered glacier was conducted at Miage Glacier in the Italian Alps (Brock and others, 2010). Although both Miage Glacier and $24 \mathrm{~K}$ Glacier likely experience significant interannual variability in meteorology, the comparison of meteorological variables and energy fluxes between the two glaciers is potentially helpful for understanding the different mechanism of glacier response in the Himalaya compared with the European Alps. Comparison of the available energy fluxes during the 2005 ablation season on Miage Glacier (Table 4) with those for $24 \mathrm{~K}$ Glacier in the present study indicates that there is a significant difference in $L_{\text {in }}$ and $S_{\text {in, }}$ which reflects the different climatic contexts of glaciers in the European Alps and in the Himalaya. The $24 \mathrm{~K}$ Glacier was significantly influenced by the Indian summer monsoon, with higher moisture, precipitation and cloud cover: relative humidity at $24 \mathrm{~K}$ Glacier was $\sim 81.4 \%$, in contrast to the value of $66 \%$ for the Miage Glacier. In addition, total precipitation was $\sim 5$ times greater in the case of $24 \mathrm{~K}$ Glacier (Table 4). The monsoonal climate is therefore characterized by higher $L_{\text {in }}$ but smaller $S_{\text {in. }}$. In addition, the albedo of the dark debris material at the $24 \mathrm{~K}$ Glacier (0.05) is significantly lower than that at Miage Glacier (0.13), reflecting differences in debris lithology. The energy supply $\left(S_{\text {net }}+L_{\text {in }}: 545.8 \mathrm{~W} \mathrm{~m}^{-2}\right)$ at $24 \mathrm{~K}$ Glacier was $\sim 28 \mathrm{~W} \mathrm{~m}^{-2}$ higher than that at the Miage glacier in the Alps. However, the corresponding greater energy loss by $H_{\text {sen, }} L_{\text {out }}$ and $H_{\text {lat }}$ at $24 \mathrm{~K}$ Glacier, in turn, lead to a limited difference $\left(7 \mathrm{~W} \mathrm{~m}^{-2}\right)$ in $G_{d}$ compared with the Miage Glacier. This comparison indicates that despite the significant difference in energy supply in the different climatic regimes, the occurrence of a
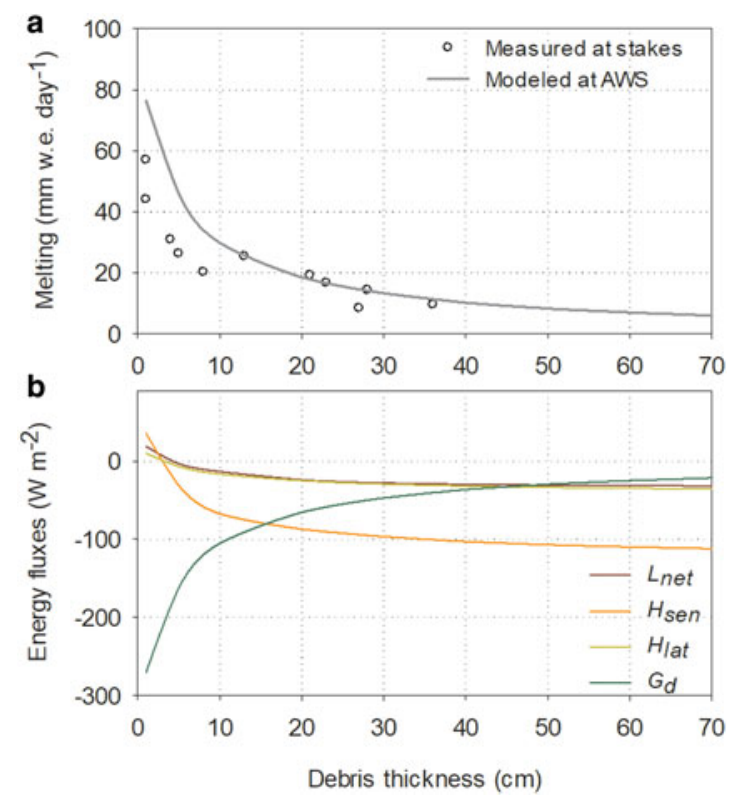

Fig. 12. (a) Measured daily melt rate at the ablation stakes and the modeled melting curve near the AWS for $24 \mathrm{~K}$ Glacier, assuming the same meteorological input, as a function of debris thickness. (b) Variations in energy components calculated for different debris thicknesses.

debris cover greatly attenuates sub-surface melting by changing the magnitude and pattern of surface energy loss.

\subsection{The role of debris thickness on surface energy balance and melting}

Previous studies have demonstrated that debris thickness greatly influences glacier melting (e.g. Sakai and others, 2002; Benn and others, 2012; Zhang and others, 2016). Based on the ablation stake measurements with different debris thicknesses on the $24 \mathrm{~K}$ Glacier (Fig. 2), there is clearly an exponential relationship between debris thickness and sub-debris ice melting (Fig. 12a). The maximum melt rate was $\sim 57 \mathrm{~mm}$ w.e. day $^{-1}$ beneath the thin debris layer $(\sim 1-2 \mathrm{~cm})$ at the upper limit of the debris cover, in spite of the relatively lower air temperature at higher elevations. The minimum melting was only $\sim 8 \mathrm{~mm}$ w.e. day ${ }^{-1}$ beneath a debris thickness of $36 \mathrm{~cm}$ at the glacier terminus. The maximum rate of change in melt rates occurred within a debris thickness of $<\sim 10 \mathrm{~cm}$, which was in agreement with previous measurements during the 2008 ablation season (Yang and others, 2010).

In order to ascertain the influence of debris thickness on melting from a surface energy perspective, the surface energy-balance model described in Section 3.2 was re-run under different debris thicknesses and under a clear-ice condition with the assumed same meteorological conditions at the AWS location. The experiment under different debris thicknesses ignored the warming effect of debris on the air temperature because of the limited availability of data required to quantitatively exclude the effect (Brock and others, 2010). The theoretical melting curve and energy fluxes in relation to debris thickness at the location of the AWS at $3900 \mathrm{~m}$ a.s.I are illustrated in Fig. 12b. It is clear that with the decrease in debris thickness, the energy consumption by $H_{\text {sen }}$ is dramatically reduced while $G_{\mathrm{d}}$ increases synchronously. Although the magnitudes of changes in both 
$L_{\text {net }}$ and $H_{\text {lat }}$ were dissimilar to that of $H_{\text {sen }}$ they exhibited a similar pattern of decrease to $H_{\text {sen }}$. Notable changes in $G_{d}$ from -270 to $-105 \mathrm{~W} \mathrm{~m}^{-2}$ occurred between a debris thickness of 1 and $10 \mathrm{~cm}$ (Fig. 12b). The rate of reduction in $G_{d}$ was attenuated with a thickness ranging from $10 \mathrm{~cm}$ to $40 \mathrm{~cm}$ and exhibited a negligible change when the debris thickness exceeded $\sim 40 \mathrm{~cm}$. When the AWS location at $24 \mathrm{~K}$ was assumed to be bare ice, similar to Parlung No. 4 Glacier, turbulent heat fluxes were calculated by using the debris-free glacier energy-balance model in Section 3.1 by assuming the mean ice albedo of 0.25 and the same ice roughness of $0.8 \mathrm{~mm}$. The results showed that $L_{\text {net }}$ changed from -25 to $+28 \mathrm{~W} \mathrm{~m}^{-2}, H_{\text {sen }}$ from -87 to $+6.1 \mathrm{~W} \mathrm{~m}^{-2}$, and $H_{\text {lat }}$ from -25 to $+5.7 \mathrm{~W} \mathrm{~m}^{-2}$. The total energy for melting would increase greatly to $-199.4 \mathrm{~W} \mathrm{~m}^{-2}$. This means that the existence of the $25 \mathrm{~cm}$ thick debris layer would produce a $68 \%$ decrease in the energy for melting compared with assumed bare ice conditions. When the debris was sufficiently thin $(\sim 1-2 \mathrm{~cm})$, the surface debris temperature was actually as low as the melting point $\left(0^{\circ} \mathrm{C}\right)$. The sign of $H_{\text {sen, }} H_{\text {lat }}$ and $L_{\text {net }}$ turned from negative to positive, indicating a shift from energy consumption to energy supply and greater energy transport from the warm and humid air to the glacier surface. Consequently, the maximum ablation generally occurs in the thin layers due to both the greater absorption of $S_{\text {in }}$ as a result of the low surface albedo and the pattern of changes in the surface energy balance. However, in the upper sections of the glacier, the sparsely scattered thin debris cover would have a higher albedo than a completely debris-covered surface. When the debris cover is less than a certain 'effective thickness' (Kirkbride and Dugmore, 2003), the melt rate will decrease towards the bare-ice melt rate as the debris thickness tends toward zero, which is in agreement with the 'Østrem curve' (Østrem, 1959). Therefore, melting on the debris-covered $24 \mathrm{~K}$ Glacier not only depends on the energy supply from the atmosphere, but is also critically linked to the distribution of debris thickness which will alter the patterns and magnitudes of supply and consumption (in particular of $H_{\text {sen, }} H_{\text {lat }}$ and $L_{\text {net }}$ ), especially beneath a thin $(<10 \mathrm{~cm})$ debris layer.

\section{CONCLUSIONS}

We have conducted a comparative investigation of the meteorology and surface energy balance of a debris-free and a debris-covered glacier in the southeastern Tibetan Plateau. Although the distance between the two glaciers is only $120 \mathrm{~km}$, there are considerable differences in the meteorological conditions and energy balance due to the contrasting surface conditions and local climatic backgrounds. Notable differences in temporal fluctuations of meteorological variables between the two glaciers occur in precipitation, $S_{\text {in }}$ and wind speed; and they may reflect local factors such as topography, glacier scale and surface conditions (snow/ice, debris). The total precipitation amount at $24 \mathrm{~K}$ Glacier was approximately nine times larger than that at Parlung No. 4 Glacier. In contrast, the wind speeds were on average 1.8 times higher at Parlung No. 4 Glacier. During the whole observational period, the daily mean $S_{\text {in }}$ at $24 \mathrm{~K}$ Glacier was generally lower than that at Parlung No. 4 Glacier, except for August. Other variables, including air temperature, relative humidity and $L_{\text {in, }}$ exhibited a simultaneous pattern of fluctuations, indicating a synoptic-scale pattern in the monsoon-influenced southeastern Tibetan Plateau. The $24 \mathrm{~K}$ Glacier experiences a relatively warmer and wetter climate, while the Parlung No. 4 Glacier experiences a colder and drier climate.

Although the two glaciers received the same amount of $S_{\text {in }}$ during the observational period $\left(\sim 213 \mathrm{~W} \mathrm{~m}^{-2}\right)$, more solar energy ( $58 \mathrm{~W} \mathrm{~m}^{-2}$ ) was absorbed at the debris surface due to the lower mean surface albedo (0.05). In addition, the warm and humid air at the $24 \mathrm{~K}$ Glacier contributed $\sim 45 \mathrm{~W} \mathrm{~m}^{-2}$ more to $L_{\text {in }}$ than at the Parlung No. 4 Glacier; therefore, the radiation supply was significantly greater in the area of the $24 \mathrm{~K}$ Glacier. However, the debris cover provided effective insulation for the underlying ice by returning energy to the atmosphere in the form of $H_{\text {sen, }} L_{\text {out }}$ and $H_{\text {lat }}$ (evaporation). The existence of a debris layer not only led to the differences in surface albedo (0.05 vs 0.32 ), but was also responsible for the differences in energy fluxes including the $L_{\text {out }}\left(-370 \mathrm{~W} \mathrm{~m}^{-2}\right.$ for $24 \mathrm{~K}$ Glacier vs $-316 \mathrm{~W} \mathrm{~m}^{-2}$ for Parlung No. 4 Glacier) and the turbulent fluxes $\left(H_{\text {sen }}:-87 \mathrm{~W} \mathrm{~m}^{-2}\right.$ for $24 \mathrm{~K}$ Glacier vs $+17 \mathrm{~W} \mathrm{~m}^{-2}$ for Parlung No. 4 Glacier; $H_{\text {lat }}:-25 \mathrm{~W} \mathrm{~m}^{-2}$ for $24 \mathrm{~K}$ Glacier vs $+1.5 \mathrm{~W} \mathrm{~m}^{-2}$ for Parlung No. 4 Glacier) between the debris-free and debris-covered glaciers. In addition, comparison of energy fluxes between overcast and clear-sky weather conditions revealed that the compensation by increase $L_{\text {in }}$ for lower levels of $S_{\text {in }}$ contributed to the similar magnitude of energy fluxes for melting between clear-sky and overcast conditions at Parlung No. 4 Glacier. A contrasting $S_{\text {in }}-H_{\text {sen }}$ compensation pattern dominated at the debris-covered $24 \mathrm{~K}$ Glacier. Overall, the energy available for melting in clear sky condition was $18 \mathrm{~W} \mathrm{~m}^{-2}$ more than that in overcast conditions at $24 \mathrm{~K}$ Glacier.

In addition, both in situ measurements and a sensitivity experiment indicated that debris thickness greatly influences glacier melting within a $\sim 10 \mathrm{~cm}$ range of debris thickness, due to the dramatic positive-direction changes in energy components. With the decrease in debris thickness, the energy consumption by turbulent heat fluxes and outgoing longwave radiation would be dramatically reduced and the sign of turbulent heat fluxes and net longwave radiation turned from negative to positive when the debris was sufficiently thin. Comparison of meteorological variables and energy fluxes between the 2009 and 2016 ablation seasons at Parlung No. 4 Glacier indicated that the change in monsoonal precipitation and katabatic wind could significantly influence the magnitude of surface melting by changing the energy input of $S_{\text {in }}$ and sensible heat fluxes. Finally, more detailed studies of the spatiotemporal variation of monsoonal precipitation and debris thickness are needed for future regional glaciological and hydrological studies in this mountainous glacierized region.

\section{ACKNOWLEDGEMENTS}

Special thanks to T.M. Reid for providing the debris surface energy balance model. The meteorological data exploited in this study are available at the Third Pole Environment Database (http://en.tpedatabase.cn/). We thank two anonymous reviewers and scientific editor Dr Joe Shea for valuable insights that greatly strengthened the manuscript. This study was jointly funded by the National Natural Science Foundation of China (Grants 91547104, 91647205 and 41371085) and the Chinese Academy of Sciences (Grant QYZDY-SSW-DQC003). 


\section{REFERENCES}

Anderson B and Mackintosh A (2012) Controls on mass balance sensitivity of maritime glaciers in the Southern Alps, New Zealand: the role of debris cover. J. Geophys. Res., 117(F1), 1003 (doi: 10.1029/2011JF002064)

Azam MF and 6 others (2014) Processes governing the mass balance of Chhota Shigri Glacier (Western Himalaya, India) assessed by point-scale surface energy balance measurements. Cryosphere. 8(6), 2195-2217 (doi: 10.5194/tc-8-2195-2014)

Benn DI and 9 others (2012) Response of debris-covered glaciers in the Mount Everest region to recent warming, and implications for outburst flood hazards. Earth-Sci. Rev., 114(1-2), 156-174 (doi: 10.1016/j.earscirev.2012.03.008)

Bolch T and 9 others (2012) The state and fate of Himalayan glaciers. Science, 336(6079), 310-314 (doi: 10.1126/science.1215828)

Brock B, Rivera A, Casassa G, Bown F and Acuñn C (2007) The surface energy balance of an active ice-covered volcano: Villarrica Volcano, southern Chile. Ann. Glaciol., 45(1), 104-114 (doi: 10.3189/172756407782282372)

Brock BW and 5 others (2010) Meteorology and surface energy fluxes in the 2005-2007 ablation seasons at the Miage debriscovered glacier, Mont Blanc Massif, Italian Alps. J. Geophys. Res., 115, D09106 (doi: 10.1029/2009JD013224)

Brun F, Berthier E, Wagnon P, Kääb A and Treichler D (2017) A spatially resolved estimate of High Mountain Asia glacier mass balances from 2000 to 2016. Nat. Geosci., 10, 668-673 (doi: 10.1038/NGEO2999).

Collier E and 5 others (2015) Impact of debris cover on glacier ablation and atmosphere-glacier feedbacks in the Karakoram. Cryosphere., 9(4), 1617-1632 (doi: 10.5194/tc-9-1617-2015)

Conway JP and Cullen NJ (2016) Cloud effects on surface energy and mass balance in the ablation area of Brewster Glacier, New Zealand. Cryosphere, 10(1), 975-1019.(doi: 10.5194/tc-10313-2016)

Drewry DJ (1972) A quantitative assessment of dirt-cone dynamics. J. Glaciol., 11(63), 431-446

Fujita K and Sakai A (2014) Modelling runoff from a Himalayan debris-covered glacier. Hydrol. Earth. Syst. Sciences., 18(7), 2679-2694 (doi: 10.5194/hess-18-2679-2014).

Giesen RH, Van Den Broeke MR, Oerlemans J and Andreassen LM (2008) Surface energy balance in the ablation zone of Midtdalsbreen, a glacier in southern Norway: interannual variability and the effect of clouds. J. Geophys. Res., 113(D21), 6089-6098 (doi: 10.1029/2008JD010390).

Greuell W and Böhm R (1998) 2 m temperatures along melting midlatitude glaciers, and implications for the sensitivity of the mass balance to variations in temperature. J. Glaciol., 44(146), 9-20 (doi: 10.1017/S0022143000002306)

Guo X and 7 others (2011) Critical evaluation of scalar roughness length parametrizations over a melting valley glacier. Bound. Layer. Meteorol., 139, 307-332 (doi: 10.1007/s10546-0109586-9)

Hagg W, Mayer C, Lambrecht A and Helm A (2008) Sub-debris melt rates on southern Inylchek Glacier, central Tian Shan. Geogr. Ann., 90A(1), 55-63 (doi: 10.1111/j.1468-0459.2008.00333.x)

Han H, Ding Y and Liu S (2006) A simple model to estimate ice ablation under a thick debris layer. J. Glaciol., 52(179), 528-536 (doi: 10.3189/172756506781828395)

He D, Li S and Zhang Y (2007) The variation and regional differences of precipitation in the Longitudinal Range-Gorge the Region. Chinese. Sci. Bull., 52, 59-73 (doi: 10.1007/s11434007-7007-3)

Hofer M, Marzeion B and Mölg T (2015) A statistical downscaling method for daily air temperature in data-sparse, glaciated mountain environments. Geosci. Model. Dev., 8(3), 579-593 (doi: 10.5194/gmd-8-579-2015)

Huintjes E and 9 others (2015) Evaluation of a coupled snow and energy balance model for Zhadang glacier, Tibetan Plateau, using glaciological measurements and time-lapse photography.
Arctic. Antarct. Alp. Res., 47(3), 573-590 (doi: 10.1657/ AAAR0014-073)

Immerzeel WW, Van Beek LP and Bierkens MF (2010) Climate change will affect the Asian water towers. Science., 328(5984), 1382-1385 (doi: 10.1126/science.1183188)

Kääb A, Treichler D, Nuth C and Berthier E (2015) Brief communication: contending estimates of 2003-2008 glacier mass balance over the Pamir-Karakoram-Himalaya. Cryosphere., 9 (2), 557-564 (doi: 10.5194/tc-9-557-2015)

Kirkbride MP and Dugmore AJ (2003) Glaciological response to distal tephra fallout from the 1947 eruption of Hekla, south Iceland. J. Glaciol., 49(49), 420-428 (doi: 10.3189/172756503781830575)

Maussion F and 5 others (2013) Precipitation seasonality and variability over the Tibetan Plateau as resolved by the High Asia Reanalysis. J. Climate., 27(5), 1910-1927 (doi: 10.1175/JCLI-D13-00282.1)

Mihalcea C and 5 others (2006) Ice ablation and meteorological conditions on the debris-covered area of Baltoro glacier, Karakoram, Pakistan. Ann. Glaciol., 43(1), 292-300 (doi: 10.3189/172756406781812104)

Mihalcea C and 7 others (2008) Spatial distribution of debris thickness and melting from remote-sensing and meteorological data, at debris-covered Baltoro glacier, Karakoram, Pakistan. Ann. Glaciol., 48(1), 49-57 (doi: 10.3189/172756408784700680)

Mölg T, Maussion F and Scherer D (2014) Mid-latitude westerlies as a driver of glacier variability in monsoonal High Asia. Nat. Clim. Change., 4(1), 68-73 (doi: 10.1038/nclimate2055)

Nakawo M and Rana B (1999) Estimate of ablation rate of glacier ice under a supraglacial debris layer. Geogr. Ann., 81(4), 695-701 (doi: 10.1111/1468-0459.00097).

Nakawo M and Young GJ (1982) Estimate of glacier ablation under a debris layer from surface temperature and meteorological variables. J. Glaciol., 28(98), 29-34. (doi: 10.1017/S002214300001176X)

Nicholson L and Benn DI (2012) Properties of natural supraglacial debris in relation to modelling sub-debris ice ablation. Earth Surf. Proc. Land., 38(5), 490-501 (doi: 10.1002/esp.3299)

Nicholson LI, Prinz R, Mölg T and Kaser G (2013) Micrometeorological conditions and surface mass and energy fluxes on Lewis Glacier, Mt Kenya, in relation to other tropical glaciers. Cryosphere., 7(4), 1205-1225 (doi: 10.5194/tc-71205-2013)

Østrem G (1959) Ice melting under a thin layer of moraine, and the existence of ice cores in moraine ridges. Geogr. Ann., 41(4), 228-230

Reid T and Brock B (2010) An energy-balance model for debris-covered glaciers including heat conduction through the debris layer. J. Glaciol., 56(199), 903-916 (doi: 10.3189/002214310794457218)

Reid T, Carenzo M, Pellicciotti F and Brock B (2012) Including debris cover effects in a distributed model of glacier ablation. J. Geophys. Res., 117(D18), 18105 (doi: 10.1029/2012JD017795)

Rounce DR and McKinney DC (2014) Debris thickness of glaciers in the Everest area (Nepal Himalaya) derived from satellite imagery using a nonlinear energy balance model. Cryosphere., $\mathbf{8}(4)$, 1317-1329 (doi: 10.5194/tc-8-1317-2014)

Rounce DR, Quincey DJ and McKinney DC (2015) Debris-covered glacier energy balance model for Imja-Lhotse Shar Glacier in the Everest region of Nepal. Cryosphere., 9(6), 2295-2310 (doi: 10.5194/tcd-9-3503-2015)

Rowan AV, Egholm DL, Quincey DJ and Glasser NF (2015) Modelling the feedbacks between mass balance, ice flow and debris transport to predict the response to climate change of debris-covered glaciers in the Himalaya. Earth. Planet. Sci. Lett., 430, 427-438 (doi: 10.1016/j.epsl.2015.09.004)

Sakai A, Nakawo M and Fujita K (2002) Distribution characteristics and energy balance of ice cliffs on debris-covered glaciers, Nepal Himalaya. Arctic. Antarct. Alp. Res., 34(1), 12-19 (doi: 10.2307/ 1552503)

Schauwecker S and 7 others (2015) Remotely sensed debris thickness mapping of Bara Shigri Glacier, Indian Himalaya. J. Glaciol., 61(228), 675-688 (doi: 10.3189/2015JoG14J102) 
Scherler D, Bookhagen B and Strecker MR (2011) Spatially variable response of Himalayan glaciers to climate change affected by debris cover. Nat. Geosci., 4(3), 156-159 (doi: 10.1038/ ngeo1068)

Shaw TE and 5 others (2016) Air temperature distribution and energy-balance modelling of a debris-covered glacier. J. Glaciol., 62(231), 185-198 (doi: 10.1017//jog.2016.31)

Shea JM and 5 others (2015) A comparative high-altitude meteorological analysis from three catchments in the Nepalese Himalaya. Int. J. Water. Resour. D., 31(2), 174-200 (doi: 10.1080/07900627.2015.1020417).

Shi Y, Liu C and Wang Z (2008) Concise glacier inventory of China, Shanghai Popular Science Press, Shanghai

Steiner JF and Pellicciotti F (2015) Variability of air temperature over a debris-covered glacier in the Nepalese Himalaya. Ann. Glaciol., 57(71), 295-307 (doi: 10.3189/2016AoG71A066)

Steiner JF and 5 others (2015) Modelling ice-cliff backwasting on a debris-covered glacier in the Nepalese Himalaya. J. Glaciol., 61(229), 889-907 (doi: 10.3189/2015JoG14J194)

Sun W and 9 others (2014) Ablation modeling and surface energy budget in the ablation zone of Laohugou glacier No. 12, western Qilian mountains, China. Ann. Glaciol., 55(66), 111-120 (doi: 10.3189/2014AoG66A902)

Takeuchi Y, Kayastha RB and Nakawo M (2000) Characteristics of ablation and heat balance in debris-free and debris-covered areas on Khumbu Glacier, Nepal Himalayas, in the premonsoon season. IAHS Puhl., 246, 53-62

van den Broeke MR (1997) Structure and diurnal variation of the atmospheric boundary layer over a mid-latitude glacier in summer. Bound. Layer. Meteorol., 83(2), 183-205 (doi: 10.1023/A:1000268825998) van den Broeke MR, Reijmer C, Van As D and Boot W (2006) Daily cycle of the surface energy balance in Antarctica and the influence of clouds. Int. J. Climatol., 26, 1587-1605 (doi: 10.1002/ joc.1323)

Yang W and 6 others (2011) Summertime surface energy budget and ablation modeling in the ablation zone of a maritime Tibetan glacier. J. Geophys. Res., 116(D14), D14116 (doi: 10.1029/ 2010JD015183)

Yang W, Yao T, Xu B and Zhou H (2010) Influence of supraglacial debris on summer ablation and mass balance in the $24 \mathrm{~K}$ Glacier, southeast Tibetan Plateau. Geogr. Ann., 92A(3), 353-360 (doi: 10.1111/j.1468-0459.2010.00400.x).

Yang W, Guo X, Yao T, Zhu M and Wang Y (2016) Recent accelerating mass loss of southeast Tibetan glaciers and the relationship with changes in macroscale atmospheric circulations. Clim. Dynam., 47(3-4), 805-815 (doi: 10.1007/s00382-0152872-y)

Yao T and 14 others (2012) Different glacier status with atmospheric circulations in Tibetan Plateau and surroundings. Nat. Clim. Change., 2(9), 663-667 (doi: 10.1038/nclimate1580)

Ye D and Gao Y (1979) Meteorology of the Tibetan Plateau. Science Press, Beijing, 49-61.

Zhang Y, Fujita K, Liu S, Liu Q and Nuimura T (2011) Distribution of debris thickness and its effect on ice melt at Hailuogou glacier, southeastern Tibetan Plateau, using in situ surveys and ASTER imagery. J. Glaciol., 57(206), 1147-1157 (doi: 10.3189/ $002214311798843331)$

Zhang Y, Hirabayashi Y, Fujita K, Liu S and Liu Q (2016) Heterogeneity in supraglacial debris thickness and its role in glacier mass changes of the Mount Gongga. Sci. China. Earth. Sci., 59(1):170-184 (doi: 10.1007/s11430-015-5118-2).

MS received 28 February 2017 and accepted in revised form 7 November 2017; first published online 5 December 2017 